\title{
Boundary Spanning and Gatekeeping Roles of UK Audit Committees
}

\author{
Vivien Beattie, ${ }^{a}$ Stella Fearnley ${ }^{b}$ and Tony Hines ${ }^{c}$
}

\author{
${ }^{a}$ Vivien Beattie (corresponding author) \\ Distinguished Professor of Accounting \\ Lancaster University Management School \\ Bailrigg \\ Lancaster \\ Tel. +44(0)1524 594334 \\ Email v.beattie@lancaster.ac.uk \\ b Stella Fearnley \\ Professor of Accounting \\ Executive Business Centre \\ BournemouthUniversity \\ 89 Holdenhurst Road \\ Bournemouth BH8 8EB \\ Tel. +44(0)1202 968741 \\ Email s.fearnley@bournemouth.ac.uk \\ c. Tony Hines \\ Principal Lecturer in Accounting \\ University of Portsmouth \\ Richmond Building \\ Portland Street \\ Portsmouth PO1 3DE \\ Tel. +44(0)2392844156 \\ Email Tony.hines@port.ac.uk
}

Acknowledgments:

We would like to thank The Institute of Chartered Accountants in England and Wales' charitable trusts for financial support on this project. Thanks also go to: John Coombe, Ken Lever, Ian Percy and Gerald Russell who have acted as general advisors to the project (including pilot testing the questionnaire); Steve Maslin who also helped pilot test the questionnaire; and the 100 Group of Finance Directors, the ICAEW's Audit and Assurance Faculty and many audit firms who gave their support. Particular thanks go to the 498 individuals who completed the questionnaire on which this paper is based. We appreciate the comments of participants at the British Accounting Association's Annual conference in 2009, the European Accounting Association's Annual Conference in 2009 and the UK National Auditing Conference in 2011. Particular thanks go to two anonymous ABR reviewers for their very constructive comments and suggestions.

Note to paper:

The editorial process for this paper was undertaken by Pauline Weetman, former ABR editor. 


\title{
Boundary Spanning and Gatekeeping Roles of UK Audit Committees
}

\begin{abstract}
Post financial crisis, audit committee (AC) reforms are proposed to improve the quality of financial reporting (EC 2011; Competition Commission 2013). This paper's empirical contribution is to investigate the extent to which ACs and audit committee chairs (ACCs) engage with chief financial officers (CFOs) and audit partners (APs) across a range of 32 financial reporting issues. It is the first large-scale survey of interactions to move beyond the micro CFO / AP dyad and to distinguish the individual ACC from the AC group. While $37 \%$ of the 5,445 reported discussions involve all three key individuals together with the full AC, 35\% involve neither the AC nor the ACC and the ACC acts without the full AC in a significant minority of cases. The parties reported to be involved are similar across the three respondent groups but vary with financial reporting issue, company size and audit firm size. The paper's theoretical contribution is to interpret the evidence using the concepts of boundary spanning and gatekeeping roles. The research reveals incomplete levels of $\mathrm{AC}$ and ACC engagement with financial reporting issues. Findings have implications for policymakers regarding the role, influence and effectiveness of the AC in financial reporting matters. Directions for future research are identified.
\end{abstract}

Keywords: auditor-client interaction; audit committee; boundary spanning; corporate governance; discussion; negotiation. 


\section{Boundary Spanning and Gatekeeping Roles of UK Audit Committees}

\section{INTRODUCTION}

Following the banking crisis, regulatory reforms relating to corporate governance, financial reporting and the role of auditors are currently being considered in various national and supranational jurisdictions. In relation specifically to audit committees (ACs), the EC is proposing a regulation to mandate engagement by auditors with audit committees (ACs) in EU public interest entities regarding audit and financial reporting issues (EC 2011, para. 23). In the UK, the Competition Commission, in its statutory investigation of the audit market, concluded that the accountability of the external auditor to the AC should be strengthened as one of seven remedies for the adverse effect of high concentration on competition (Competition Commission 2013, pp. 265-274). Further, the UK Corporate Governance Code contains a new requirement (to come into effect in late 2013) for AC reports to give a description of significant issues considered by the AC in relation to the financial statements and how these issues were addressed (FRC 2012). These reforms all focus on the engagement of the AC as a means to improve the quality of financial reporting.

In recent years, a major influence on AC regimes in many countries was the passing of the US Sarbanes-Oxley Act (SOX) in 2002 which instituted mandatory reforms designed to restore confidence in US corporate governance, financial reporting and auditing after the Enron scandal and the collapse of Andersen. SOX provisions impacted entities beyond the US since they also applied to foreign subsidiaries and foreign registrants with US listings and came to be viewed as best practice. A key feature of SOX was to mandate the strengthening of the role of the AC in its engagement with auditors in financial reporting and auditing issues and also to mandate the engagement of auditors with the AC. The influence of SOX led to changes in AC regimes throughout the EU and particularly in the UK (Smith Committee 2003).

Comparative studies of AC practices in the EU suggest that there are significant differences in AC regimes, particularly between what is referred to as the Anglo-Saxon market-based governance model and the continental European / Japanese insider 
stakeholder model (Collier and Zaman 2005, Cicon et al. 2012). The market-based approach is short-term and shareholder-centric, whereas the insider stakeholder model adopts a longer-term view and is responsive to diverse interests and accountabilities (GarcíaCastro et al. 2013). Some evidence is emerging within the EU of a move towards the Anglo-Saxon US / UK style regime for ACs; a model which draws mainly on the US model (Kumar and Zattoni 2013). However the extent of the adoption of the Anglo-Saxon model varies significantly between EU countries (Coffee 2006, Oxley 2007, Quick et al. 2007).

The mandatory adoption of International Financial Reporting Standards (IFRS) for the group accounts of all EU listed companies from 2005 resulted in a more technically complex accounting regime for listed companies, placing considerable strain on ACs, audit committee chairs (ACCs), chief financial officers (CFOs) and audit partners (APs) (Beattie Fearnley and Hines. 2011 (hereafter BFH), ch.16). It is now widely recognised that the engagement of the AC with the financial reporting and auditing process has changed (e.g. Sabia and Goodfellow 2005, KPMG 2006, 2010, 2013a,b). ACs have emerged as a key influence in the financial reporting process, although there has been relatively little research about the actual level of engagement between the key parties. While small-sample case studies have been carried out in the UK by Turley and Zaman (2007) and BFH, in Canada by Gendron and Bédard (2006) and in Malaysia by Salleh and Stewart (2012), to date there has been no large-scale study of AC engagement specifically regarding crucial financial reporting issues. This is particularly desirable given that Beattie et al. (2012) investigated the level of involvement of key parties in relation to a range of audit-related issues and found evidence of less than full AC engagement.

In their review of auditor-client interaction research, Nelson and Tan (2005, p.58) call for research that recognises that practice has changed 'to involve audit committees and various forms of regulatory oversight to a greater extent'. This paper responds to this call by undertaking a wide ranging experiential questionnaire survey of the three principal parties in the financial reporting interaction process. Previous questionnaire studies have focussed only on the micro CFO / AP dyad (see, for example, Beattie et al. (2000) in the UK and Gibbins et al. (2007) in Canada). The present survey was conducted in the 2007 UK regulatory environment, which is fundamentally unchanged 
at the present time. ${ }^{1}$ It complements the limited extant case study research on the CFO / AP / AC triad previously undertaken by providing large scale data suitable for statistical analysis and permitting generalisation. The paper is situated at the juncture of the financial reporting interaction literature (which largely ignores the role of ACs) and the AC literature (which focusses on inputs and outputs and largely ignores process aspects).

Our research questions concern the financial statement issues which are the subject of discussions between CFOs, APs and / or ACCs. AC engagement in these discussions is conceived as a two-stage process: awareness and involvement. Awareness is a necessary, but not sufficient, condition for involvement. First, we explore the extent to which the ACCs' level of awareness of financial reporting interaction issues (both generally and with respect to specific issues) is similar to the other two respondent groups (APs and CFOs). Second, we examine the extent to which the ACC and the full AC are routinely involved in discussions related to the production of financial statements. Finally, we investigate the extent to which factors such as financial reporting issue, company size and audit firm tier impact upon the engagement of the parties in the interactions.

The primary empirical contribution of the paper is to provide the first large-sample evidence of the extent to which ACs are engaged in financial reporting issues in the post-SOX, Anglo-Saxon corporate governance environment. There are two important secondary empirical contributions: (i) the engagement of the ACC is considered separately from the full AC and (ii) contextual factors that may influence the extent of engagement are explored. Given the key role of ACs in proposed regulatory change, this evidence offers a valuable baseline for future academic research and policy-making. The theoretical contribution of the paper is to highlight the role of the ACC (and the AC) as boundary spanners and gatekeepers, constructs drawn from the organisational studies literature. To our knowledge, the only study to date to characterise the AC in this way is Seabright et al. (1992), who focus on the issue of auditor-client realignments. This paper will inform national and supranational regulators who are currently considering further changes to AC regimes in respect of $\mathrm{AC}$ engagement with financial reporting issues. The extent of AC engagement in this core area of an AC's remit provides new insights into a key aspect of AC effectiveness under the UK Anglo-Saxon style governance 
regime. Our findings respond to the growing call for evidence-based policy making that assesses the effects of financial regulation (e.g. Buijink 2006).

Findings are based on questionnaire responses from 498 individuals (130 ACCs, 149 CFOs and 219 APs) linked to UK listed companies. The main findings are that, while $37 \%$ of the 5,445 reported discussions involve all three key individuals together with the full AC, 35\% involve neither the AC nor the ACC and the ACC acts without the full AC in a significant minority of cases. The parties reported to be involved are similar across the three respondent groups but vary with financial reporting issue; company and auditor firm size.

The remainder of this paper is structured as follows. The next section, the literature review, is in four sections. Section 2.1 briefly describes the development of the UK corporate governance framework; section 2.2 examines the impact of national differences on corporate governance regimes; section 2.3 sets out theoretical perspectives (in particular the boundary spanning and gatekeeping roles) of ACs and ACCs; and section 2.4 focuses on research into AC practices and behaviour and, in particular, the limited literature on the AC's involvement in financial reporting interactions. Section three develops research questions, section four discusses the methods used in the study, section five presents results and discussion, and section six summarises and concludes.

\section{LITERATURE REVIEW}

\subsection{Development of the UK corporate governance framework}

The UK financial scandals (e.g. Maxwell and BCCI) of the early 1990s prompted the first formal corporate governance framework, the Cadbury Report (1992). Regulatory reviews of this framework have since been undertaken regularly. The Smith Committee (2003), which was set up after the Enron scandal, made the principal recommendations about AC engagement with external auditors and financial reporting. Prior to the Smith Committee, which followed the passing of SOX in the US, the UK corporate governance code focussed primarily on improving the internal management of the company.

The entire system of business regulation in the UK is described as a 'market-based approach' which emphasises the company-shareholder relationship (FRC 2006a). The 
Financial Conduct Authority, the market regulator, requires listed companies to provide a 'comply or explain' statement in their annual report which explains how the corporate governance code has been applied by the company. In particular, an explanation is needed whenever the code's recommendations are not followed (FRC 2006a, p.7, ICAEW 2006, p.18), an approach which differs radically from the mandatory requirements in SOX. The code provisions relevant to audit committees and financial reporting require the company board to establish an AC of at least 3 (or 2 for smaller companies) independent non-executive directors, at least one of whom has recent and relevant financial experience (FRC 2006b, §C3.1). The AC is expected to monitor the integrity of the financial statements of the company, reviewing significant financial reporting judgements contained in them and discuss with the auditor issues that have been resolved and those which are unresolved. Further changes introduced in the 2012 revision require a description of the significant issues considered by the $\mathrm{AC}$ in the annual report (FRC 2012, §C.3.8). These changes will begin to appear in late 2013.

Thus, the significance and remit of the AC as a means of communicating with the external auditor about financial reporting and auditing matters has grown. The AC, as a sub-committee of the main board, remains subject to influence (power) from the main board. However, UK case study evidence suggests that the influence of either individual executive board members (particularly the CEO) or of the main board acting as a group has declined as corporate governance structures have strengthened (c.f. Beattie et al. 2001 and BFH). In addition to formal reporting by the AC to the main board, informal messages and advice occur by means of board member attendance at AC meeting (as reported in BFH 2011, p.45).

The UK auditing standard that governs communication between the auditor and those charged with governance is ISA (UK\&I) $260^{2}$ (APB 2004). This standard mirrors the corporate governance code, requiring auditors to engage with the AC on financial reporting matters (Turley 2007, p.218). 'Comply or explain' does not apply to UK auditors as compliance with auditing standards is mandatory. Auditors' work is subject to independent inspection by the Financial Reporting Council's Audit Inspection Unit, thus non-compliance with ISA 260 (UK \& I) by auditors can be exposed. 
The change to IFRS in 2005 greatly increased the complexity of the financial statements and caused ACs, ACCs and CFOs to become more reliant on their auditors for technical support in dealing with IFRS (BFH 2011, pp.250-6). Because of the complexity of IFRS, the role of the AC and the ACC also became more important in monitoring the financial statements for the benefit of the company board.

The EC proposals regarding ACs and financial reporting (EC 2011, article 31) require an AC to have one member with audit experience and one with experience in accounting or auditing. The AC should: monitor the financial reporting process and submit recommendations and proposals to ensure its integrity; monitor the statutory audit of the annual and consolidated financial statements; supervise the completeness and integrity of the draft audit reports; and monitor the effectiveness of the undertaking's internal control, internal audit and risk management systems.

\subsection{Corporate governance under different country regimes}

Countries vary significantly in their economic and institutional context (La Porta et al. 2008). Leuz (2010) analyses the different approaches to financial regulation generally, identifying institutional country clusters covering 49 countries based on 13 institutional characteristics. He argues that global convergence is unlikely due to these institutional differences and enforcement differences. The comparative corporate governance literature recognises describes two key styles (or ideal types) of national governance: the short term, outsider market-driven shareholder value model (which is seen as the AngloSaxon model and is becoming increasingly influential thorough globalisation of capital markets) and the continental European / Japanese model of a longer term, insider stakeholder-driven model (Clarke 2011). The former model is characterised by deep equity markets, low employee protection and common law system, whereas the latter is typified by code law, greater emphasis on bank financing and employee rights (for a detailed discussion, see García-Castro et al. 2013, pp.392-3). Recent evidence from 26 European countries suggests that $25 \%$ of the variation in firm performance is attributable to country-level factors embedded in these corporate governance models, rather than firm-level factors (van Essen et al. 2013).

There are currently pressures on both. The Anglo-Saxon model is under pressure to demonstrate more social responsibility and accountability and the European-Japanese 
model is under pressure to be more responsive to markets and more transparent. Clarke (2011) also refers to the key differences in board structure. Some countries such as UK have a unitary board consisting of executive and non-executive directors, while others, such as Germany, have a two-tiered structure including supervisory boards involving a wider range of stakeholders. There are also differences between code law and common law countries. Davies and Schlitzer (2008) refer to the insider / outsider corporate governance system and conclude that a one size fits all approach to global governance is not necessarily the right approach.

Collier and Zaman (2005) analyse the corporate governance codes in 20 European countries and conclude that the AC concept is widely accepted in countries with both unitary and two-tier governance systems, although there is considerable variation in the detailed recommendations covering structures and responsibilities. The assumption of global convergence towards the common law system in the EU with its shareholder focussed governance has been questioned by Cicon et al. (2010). From a thematic analysis of governance codes in $23 \mathrm{EU}$ countries, they find that some EU countries are diverging from the UK model. Böhm et al (2012) review the design of audit committees in six continental European countries following the amendment of EU Eighth Directive on Company Law and conclude that there are substantial cross-national differences. FEE (2012) finds a similar level of differences in a larger-scale study. It is however interesting that, following the financial crisis, the European Commission in a draft regulation (EC 2011, article 23) is recommending more engagement between the AC and the auditors in financial reporting matters, placing the responsibility on the auditors to report more extensively to the AC. This follows the UK model typical of the AngloSaxon model. For this reason, evidence from the UK setting has wider relevance.

2.3 Theoretical perspectives on the role of the audit committee - boundary spanning and gatekeeping

The role of the AC has generally been explained from the perspective of agency theory (Jensen and Meckling 1976) and these ideas underpin corporate governance codes in the UK and elsewhere. The AC plays a role in reducing agency costs by overseeing the effectiveness of management's financial reporting policies (e.g. Haka and Chalos 1990). However the generic governance literature (e.g. Barratt et al. 2002) has also identified non-executive directors as boundary spanners, a concept derived from resource 
dependency theory in which organisations reduce the level of environmental turbulence they face by co-opting the resources they need. Hillman and Dalziel (2003) propose that corporate boards (including presumably their sub-committees) need to be viewed from both perspectives to reflect the real world.

There is general agreement in the organisational studies literature that two distinct roles (or actions) are performed by boundary spanners: external representation and information search/processing (e.g. Aldrich and Herker 1977, Marrone 2010). The former boundary role involves understanding and influencing the complex environment in which the organisation operates, representing the organisation and mediating between it and other external organisations and maintaining or improving the political legitimacy of the organisation. Actions include persuasion and resource-seeking. In relation to the latter role, boundary role incumbents act as a filter against environmental information overload, acting autonomously on some information and consolidating or transmitting other information. Perrone et al. (2003) note that, while boundary spanners are exposed to competing expectations from their own and external organisations, role autonomy permits discretionary behaviour and promotes trust externally. The AC promotes the legitimacy of the organisation to investors and regulators. The crucial importance of the personal characteristics of boundary spanners, in addition to institutional and organisational characteristics, is emphasised by Williams (2002).

To our knowledge, only one study has applied the boundary spanner concept to ACs. A key external representation role of the AC is to ensure that company management has an appropriate relationship with the external auditor. Seabright et al. (1992) studied auditor-client relationships and concluded that attachments between boundary spanners play a major role in the maintenance of interorganisational relationships. While changes in clients' resource needs increase the likelihood of switching auditors, this is reduced by individual attachments of CFOs and members of AC. Attachment is the binding of one party to another through experience and as a result of investments in that relationship. Attachments that form between boundary spanners are a mechanism for reducing transaction costs but may become overlaid with social content that carries strong expectations of trust and abstention from opportunism (Granovetter 1985). Knowledge that there will be continued interactions in the future is likely to reinforce development of attachment with more co-operative behavior. Van de Ven (1976) 
suggests that, over time, individual attachments, which are initially important in a relationship, may be replaced by organisational attachment.

Reflecting on the evolution of ACs in the US, Sabia and Goodfellow (2005) observe that the hierarchical, linear, corporate governance model has changed, with all parties now interacting with each other in a more dynamic and interdependent way (2005, pp. 6-11). In complex organisations, individual boundary spanners may be situated within a team within the organisation. In this case, the external environment refers to actors or other teams residing outside the team boundaries (in turn these may be embedded within the organisational boundary or outside that boundary). Boundary-spanning can, therefore, occur at the individual, team and organisational levels (Marrone 2010).

In the context of the present study, the AC, as a formal sub-committee of the main board, can be viewed as a team. It is a formal element in the corporate governance structures, related to the main board by virtue of its sub-committee status. Under a new UK Corporate Governance Code provision, it will report formally to shareholders via a separate section of the corporate annual report. It engages in team boundary spanning with respect to the CFO and the main board (within the organisational boundary) and with respect to the AP and the shareholders (situated outside the organisation). However, the ACC is the team member with a key individual boundary spanning role with respect to the CFO, main board and AP. The ACC also fulfills a gatekeeping role (i.e. an information access boundary role) with respect to both the AC and (indirectly via the AC) the main board, deciding when and to what extent they should be involved with an issue (BFH 2011). ${ }^{3}$ Thus, boundary spanners act as a 'bridge' between inter- and intraorganisational groups, managing the flow of information and the expectations of actors (Williams 2002). By contrast, the gatekeeper metaphor emphasises information access and is therefore a more uni-directional concept, one which is subsumed within the information role of boundary spanners. The key actors (parties) and linkages, existing both within and outside the company, are shown in Figure $1 .{ }^{4}$

[Figure 1 about here]

\subsection{Audit interaction research and the involvement of the AC post-SOX}


Archival AC research studies post-SOX relate publicly observable structural AC indicators (such as financial experience, independence of directors and frequency of meetings) to financial reporting outputs, treating AC processes as a black box. Carcello et al. (2011) sum up the findings from over 250 such studies as follows: 'generally speaking, 'good' audit committee and board characteristics are associated with measures of 'good' accounting and auditing and with more effective internal controls' (p.3). ${ }^{5}$

A generic behavioural model of the interaction process has been developed and tested using both inductive and deductive approaches using a range of experimental, questionnaire and interview methods (e.g. Beattie et al. 2001 and 2011, Salterio 2012). This behavioural model covers the antecedents and consequences of the interactions as well as the stages of the interaction process and the elements of the process. Several authors have commented on the paucity of research into AC processes; (e.g. Turley and Zaman 2007, p.767, Bédard and Gendron 2010, p.175). It may be noted that behavioural theories of corporate governance (of which audit aspects form a part) have recently been strongly advocated as a complement to economic agency theories that ignore the socially situated nature of the practices of individual actors (e.g. Westphal and Zajac 2013),

Experimental evidence from the AP and CFO perspective is reviewed in Salterio (2012, section 6). In one of the few studies with ACs, DeZoort et al. (2008) find that, in the post-SOX US setting, AC member support for auditor-proposed adjustments is significantly higher than previously (DeZoort et al. 2003).

A number of large-scale questionnaire survey studies explore auditor-company interactions on financial reporting issues (e.g. Beattie et al., 2000 in the UK; Gibbins et al., 2007 in Canada). However these studies focus on the CFO / AP dyad and do not consider either ACCs or the AC. Consequently, these studies do not address the increasing significance of the AC role in financial reporting following the post-SOX changes. In the only study to date to cover the CFO / AP / AC triad, Beattie et al. (2012) survey UK ACCs, APs and CFOs regarding their involvement and that of the AC in a range of audit responsibilities (planning, performance and finalisation) set by the Combined Code (FRC 2006b). Thus, the focus is on audit-related issues, rather than financial reporting issues. They find evidence of partial AC engagement ${ }^{6}$, concluding that regulators should be cautious about giving ACs additional responsibilities. Finally, 
in a wide-ranging survey of 1240 AC members across 34 countries, it is found that only 54 percent say they 'drill down' to a great extent and review key assumptions underlying management's material accounting judgments and estimates (KPMG 2010). The figure for the UK was 50\% on the 2010 survey, rising to 75\% in the 2013 survey (KPMG 2013a).

In the US, there have been several recent quantitative interview studies regarding the actions and behaviour of AC members. Beasley et al. (2009) find evidence of both substantive monitoring (consistent with agency theory) and ceremonial action (consistent with institutional theory). Prior UK evidence has also found evidence of ceremonial action (Spira 1999). However, considerable variation existed between companies. Fifty-seven percent of interviewees claimed to be involved in discussion of the specific judgments/estimates/assumptions concerned with implementing an accounting policy and 67\% discussed alternative accounting treatments available under GAAP (p. 49). Cohen et al. (2010) interview 30 audit managers and partners from three of the Big Four audit firms in the US. Comparisons are made with a similar pre-SOX study (Cohen et al., 2002). It is found that ACs are believed to have become significantly more active and diligent, and to possess greater expertise and power, but may play a more passive role in resolving financial reporting disputes expecting the auditors and management to resolve the issues. They conclude that the AC's role has changed from being symbolic to being an effective monitor of a company's financial reporting process, thus producing a different result from Beasley et al. (2009) by interviewing auditors rather than ACCs. Finally, Rupley et al. (2011) report that, postSOX, US public company audit committee members believe that the features of an effective audit committee are present.

In the UK, Turley and Zaman (2007) examine interactions among key corporate governance actors using case study methods, identifying both formal and informal AC processes. They conclude that: (i) the most significant effects of the AC on governance outcomes occur outside the formal AC structures and processes; (ii) the AC has a significant influence on power relations between key organisational participants; and (iii) the AC may be used as a threat, ally or arbiter in resolving issues and conflicts. 
Revisiting the approach of Beattie, Fearnley and Brandt (hereafter BFB) (2001) in the context of the much changed 2007 / 2008 post-SOX UK regulatory framework, BFH (2011) report on nine UK listed company case studies covering entities of different size and employing different auditors. The researchers interview CFOs, ACCs and AP, exploring the financial reporting and auditing interactions. They find that the ACC (usually the most financially literate member of the AC) is fully engaged in the financial reporting process and acts as gatekeeper for the AC by managing the business of the AC and deciding which issues go on the agenda. ACCs may personally take on the monitoring role that is formally assigned to the AC and wish to be kept informed of developments on a 'no surprises' principle, leaving the AC to play a more ceremonial role at the end of an interaction, 'reviewing' or 'approving' proposed solutions, consistent with Spira (1999) and Beasley et al. (2009). They also find informal processes similar to those identified by Turley and Zaman (2007) (i.e. processes which do not involve a formal discussion at the AC meeting or even a referral of the issue to the AC). The different behaviour patterns of the individual ACC compared to the full AC resonate with the findings of Gendron and Bédard (2006). The CFOs and APs are keen to take an agreed position to the ACC or AC. None of the case interactions produced a non-compliant outcome.

There are indications in the literature that company size and audit firm size are associated with AC engagement. The nine cases in BFH (2011) included five FTSE 350 companies and four outside this group, thus permitting a comparison regarding the involvement of ACCs and ACs in the 47 interactions. In FTSE 350 companies the ACC was aware of the issue or had separate discussions outside the AC in $58 \%$ of interactions, compared with 38\% for non-FTSE 350 companies. This suggests that the FTSE 350 ACCs might be more engaged than their counterparts in smaller companies. Wider evidence on the quality of corporate governance reporting in annual reports (which may be an indicator of the quality of the underlying activity) suggests that ACs in larger companies have more successfully adapted to their new responsibilities than those in smaller companies (ICAEW / BDO 2011, Deloitte 2011).

The Audit Inspection Unit's annual public reports have included comments which suggest that ISA (UK\&I) 260 has not been applied to a consistently high standard across audit firm size categories. For example, 'Consistent with prior years, the quality of 
reporting to audit committees by smaller firms was generally of a lower standard than at major firms, with the failure to communicate matters in writing a key issue.' (AIU 2010, p. 23). The quality of information supplied to an AC will be one of the factors that determines how engaged it can be in monitoring the quality of financial reporting.

In sum, the influence of ACs in the financial reporting process has increased following the changes brought about by the passing of SOX in the US. There is also some evidence that this influence varies according to company size and audit firm size. A few behavioural, process-focused qualitative studies have been carried out on small numbers of companies and many large-scale studies have related AC attributes to financial reporting outcomes, adopting an input-output model. There is survey evidence that ACs are only partially engaged with audit issues. However, to date, there has been no wide ranging survey in any country that explores the relative levels of engagement of the ACC, AC, AP and CFO in financial reporting issues. This study contributes to filling the gap. It is recognised that the 'measurement of AC effectiveness is a complicated matter' (Bédard and Gendron 2010, p.176). We contend that AC effectiveness is a multidimensional construct; one key dimension being AC engagement (i.e. awareness and involvement) on financial reporting issues.

\section{DEVELOPMENT OF RESEARCH QUESTIONS}

Given the increased regulatory emphasis placed on the AC in strengthening financial reporting quality and the increasing engagement of ACs in financial reporting issues (e.g. Beasley et al. 2009), it is to be expected that the ACC respondents should, as a minimum position, be aware of discussions concerning financial reporting (both routine discussions involving accounting policy and accounting estimates and interactions involving an element of conflict resolution). 'Awareness' of an issue following a trigger event represents the starting point for the interaction (Salterio 2012). The ACC may become aware by being directly involved in the interaction or because other parties involved in interactions report it to them. The first research question is therefore:

RQ 1: To what extent is the ACC aware of the overall level of discussions taking place on issues related to the financial statement compared with CFOs and APs?

The level of awareness may vary according to the specific nature of the financial statement issue which is the subject of the interaction. Interaction may be informal 
(Turley and Zaman 2007) or the AC may operate differently according to the characteristics and behaviour of individual members (Gendron and Bédard 2006). Some issues are inherently more complex or serious than others (or may escalate to become so) and may prompt broader consultation or formal approval. The second research question is therefore:

$R Q$ 2: To what extent is the ACC aware of discussions taking place on specific issues relating to the financial statements compared with CFOs and APs?

The responsibilities given to the AC under the UK Corporate Governance Code (FRC, 2010) and ISA (UK and Ireland) 260 (APB, 2004) are likely to involve either the full committee or the ACC in discussions with the CFO and AP. However there is evidence that the AC and ACC are frequently not involved in audit-related discussions (Beattie et al. 2012). Spira (1999) and Beasley et al. (2009) refer to the ceremonial aspect of the AC role, while Sabia and Goodfellow (2005) and BFH (2011) refer to ACs not wishing to resolve disagreements. The third research question is therefore:

$R Q 3$ (a): To what extent is the full AC routinely involved in discussions on issues related to the financial statements; and

(b): To what extent is the ACC routinely involved in discussions on issues related to the financial statements?

A range of factors are likely to influence the parties involved in audit interactions (e.g. Bédard and Gendron 2010, Lin and Hwang 2010, Carcello et al. 2011). In particular, the nature (e.g. ex ante seriousness) of the financial reporting issue and the company and auditor characteristics, which influence the structures and processes surrounding audit interactions (Beattie et al. 2012, ICAEW / BDO 2010, AIU 2008). In particular, scale effects have been shown to be pervasive in financial reporting and auditing research, captured by company size and audit firm size. Thus, the fourth research question is:

RQ 4: To what extent do the following factors have an impact on the parties involved in discussions:

(a) financial reporting issue;

(b) company size; and

(c) audit firm size. 


\section{METHODS}

The present study utilises experiential questionnaires which ask expert respondents about specific events they have encountered (Gibbins and Qu 2005). Specifically it elicits the experiences and views of the three key participant groups in audit interactions: CFOs, ACCs and APs. Such direct survey methods provide a real life alternative to other research approaches. For example, experimental studies generally take place in an artificial simplified setting. Similarly, archival methods tend to use a proxy measure for the underlying variable of interest. Large-sample questionnaire studies complement indepth, small sample interview studies and research advances often display iterations between qualitative and quantitative methods, as conceptual models are developed, tested, revised and retested. The purpose of the present paper is to permit generalisation in relation to a limited set of interaction characteristics.

This study focuses on audit interactions (i.e. discussions and/or negotiations) related to financial reporting issues. The population of interest comprises domestic, UK listed companies, excluding AIM companies and investment trusts. AIM companies were excluded because, at the time of the study they were not required to adopt IFRS; investment trusts were excluded because, as they do not trade, their accounting, auditing and governance is different. The target sample of 500 included the top 250 qualifying companies by market capitalisation (as at $5^{\text {th }}$ February 2007) and a systematic sample (every nth company ranked by market capitalisation) of 250 from the remaining qualifying companies. Where the company had delisted, merged or demerged, or moved domicile since their last annual report, or reported under US GAAP, a replacement was sought from the same industry group and with the closest market capitalisation. Key information (name of the CFO and ACC, auditor, date of last annual report and the company contact details) was collected from annual reports, websites and databases. The initial company sample resulted in 58 companies (33 involving the top 250) where the audit committee chair had been selected more than once (in three cases, four times). The 27 cases involving non-top 250 companies were reselected, but this often produced new duplications. This reduced the final sample of ACCs to 446. The co-operation of large audit firms was enlisted to identify suitable AP respondents (i.e. those who were acting as engagement partner for qualifying listed companies) and to facilitate the distribution of the questionnaire. Each of the nine firms involved nominated a contact person to assist us. A 
maximum of 439 APs were identified as qualifying for inclusion in the survey. ${ }^{7}$ It was not possible to construct a matched sample as the identity of the AP on a particular audit was not a matter of public record in 2007. Furthermore it would be necessary to obtain permission from the client before the AP could be approached.

The research instrument, contained closed-form questions, organised into six sections. This paper reports on the section relating to the discussion and negotiation of financial statement issues between the three parties. CFOs and ACCs were asked to respond in respect of their own companies, while APs were asked to respond with reference to 'the largest UK/Channel Islands domestic listed client company for whom you act as engagement partner' (referred to as 'client $\mathrm{X}$ ' throughout the questionnaire).

The introduction to the relevant section read as follows: 'The process which each year culminates in the production of company financial statements may involve discussion between two or more parties, e.g. the finance director (FD), the auditor, normally the audit engagement partner (AP), the $\mathrm{AC}$ chair (ACC) and the $\mathrm{AC}(\mathrm{AC})$, i.e. 'the participants'. Discussion on various issues, which may arise during any time of the financial year, takes place and may lead to negotiation. Discussion was defined as: matters raised by one or more participants and considered in speech or writing.

A list of 32 financial statement issues was developed from BFB (2000), updated to include changes to financial reporting since 1997, in particular the adoption of IFRS. The issues were listed in four categories: consolidation matters (code C); primary statement issues (code PS); other accounting issues (code OA); and compliance and other regulatory issues (code C\&R). ${ }^{8}$ The general approach was to consider the financial statements and related notes line by line, in conjunction with a list of extant IASs/IFRSs, supplementing the emergent list of issues with basic issues in company law and listing requirements. The list of issues was revised based on discussion with experienced auditors and CFOs who acted as general advisors to the project (see acknowledgements on cover page) and the results of pilot testing. Four 'other (please specify)' issues were included (one at the end of each grouping). Table 1 shows the 32 issues in the order that they appeared in the questionnaire.

[Table 1 about here] 
For each of the 32 financial statement issues that had been 'the subject of discussion and/or negotiation in the most recent financial year for which your financial statements have been finalised but not necessarily published', respondents were asked: 'Which parties were involved in the discussion?', followed by four tick boxes - one each for the CFO, AP, ACC and AC. Responses explicitly related to a single year, whereas BFB (2000) asked for responses to relate to the latest three years. ${ }^{9}$

A draft questionnaire was pretested with several CFOs, ACCs and APs involved with listed companies and the content, ordering, and terminology was revised accordingly. Questionnaires were serially numbered to allow non-respondents to be followed up, and were accompanied by an explanatory letter from the researchers which included an assurance of confidentiality of responses and a return envelope. Questionnaires to CFOs and ACCs were sent direct by the researchers in June 2007, while those to APs were distributed by the audit firms to ensure anonymity of both the APs and their clients. All AP responses were also returned direct to the researchers. Two reminders were sent to CFOs and ACCs - after 10 days and 24 days. The contact in each audit firm was asked to follow up in the same way on non-responding APs at similar time intervals.

\section{RESULTS AND DISCUSSION}

\subsection{Response rates and tests for bias}

From the ACC sample 130 usable responses were received (response rate 29\%), the CFO sample produced 149 usable responses (30\%) and from the AP sample of 439, 219 usable responses were received, representing a response rate of 50\%.

To test for response bias, responders and non-responders in the CFO and ACC groups were compared on the basis of company size and audit firm size (descriptive statistic are shown in Table 2). There is no significant difference in the proportion of non-Big Four affiliated respondents $\left(\chi^{2}=2.157 ; \mathrm{p}=0.340\right.$. There are, however, differences in the distribution across Stock Exchange groups $\left(\chi^{2}=16.823 ; \mathrm{p}=0.010\right)$, with a higher proportion of FTSE 350 respondents among the ACC sample. Questionnaire validity can be undermined if respondents are not knowledgeable and engaged in the relevant practices at a senior level. As there was no evidence that this was the case ${ }^{10}$, we conclude that the risk of uninformed respondent bias in this sample is minimal. 
[Table 2 about here]

\subsection{Awareness of discussions on financial statement issues (RQ 1 and RQ 2)}

The mean, standard deviation, and median number of issues cited for each respondent type is summarised in Table 3. Discussion may comprise a simple exchange of information, such as the provision of advice from the auditor on complex or new technical matters. It may also involve elucidation and confirmation in support of the attest function. An individual might be aware that a discussion took place between two or more other parties without being directly involved themselves. Table 3 indicates that, as a group, ACCs cited a slightly higher mean number of issues discussed then the other two respondent groups, although their median was the lowest indicating a skewed distribution with possible outliers at the top end. However both measures of central tendency for ACCs are broadly in line with those for the other respondent groups, although the standard deviation indicates a larger variation in responses than for CFOs and APs. In response to RQ 1, ACCs' overall level of awareness of financial reporting discussions is comparable to that of CFOs and APs. Since a lack of awareness of issues would indicate incomplete information search activities by the ACC, it may be inferred from this that the ACC is fulfilling their individual boundary-spanning role in relation to information search on behalf of the full AC.

[Table 3 about here]

For each respondent group, the infrequency with which each of the 32 issues relating to the production of annual financial statements is reported by each group as being discussed is shown in Table 4. To focus on those issues not discussed, issues are shown in increasing frequency. The ordering is based on the ACC group, with frequency ranks shown for each group.

[Table 4 about here]

The least frequently cited issues for discussion show little variation between the three respondent groups and it is noticeable that the ACCs tended to report discussion of these items at least as frequently as the other respondent groups. Only three of the ten issues least frequently cited by ACCs were cited by a higher percentage of APs or CFOs. It is 
of note that several of the least discussed issues would be considered fundamental to the quality of financial reporting (e.g. 'substance over form/ true and fair view issues', 'maintenance of proper accounting transactions', 'going concern') but would not be expected to be an explicit feature of every audit. It would be expected that ACCs would be aware of these issues in fulfillment of their information search boundary-spanning role and this does appear to be the case. Other issues in this category might be viewed as covered by relatively straightforward accounting standards which have changed little in the recent past (e.g. plant, property and equipment). The most surprising infrequently discussed issue is 'fraud and illegal acts', given that Provision C.3.2 of the Combined Code (FRC 2008) states that one of the responsibilities of the AC is 'to review the company’s internal financial controls, and unless expressly addressed by a separate board risk committee, or by the board itself, to review the company's internal financial control and risk management systems'. A similar provision is included in the proposed EU regulation (EC 2011).

At the other end of the Table 4, the most frequent issues for discussion also vary little between the three respondent groups. Three issues relating to business combinations ('intangible assets / goodwill', 'fair value on acquisition' and 'issues in subsidiary undertakings') feature for all groups and may have been used interchangeably by respondents. This high ranking may be attributed to the requirement in IFRS 3 that identifiable intangible assets must be recognised on acquisition. This requirement was new at the time and controversial (BFH 2011). Presentation of primary statements was ranked joint second by ACCs (in common with APs) along with exceptional items (also ranked within the top ten by the other two groups). This is an area where IFRS is less restrictive than UK GAAP, as IAS 1 permits flexibility in the presentation of the income statement; this major change is likely to have provoked discussion on, for example, the presentation of reorganisation costs (BFH 2011).

There is broad agreement between the three groups on the frequency of issues discussed. Out of a possible 32 issues, only eight are significantly different (at the $5 \%$ level) between groups, but all of them involve ACCs and at least one other group. In particular, ACCs are significantly less likely than APs to cite share based payments, issues in subsidiary undertakings and fraud and illegal acts as a discussion issue. In relation to these three issues, ACCs show a similar level of awareness of such issues as CFOs (though not 
APs), suggesting that they are only in part fulfilling the information search role in relation to these important issues.

There are five issues significantly more likely to be cited by the ACCs than at least one other group. These are: issues in associates and joint ventures, maintenance of proper accounting records (cited by APs), identification of pre / post acquisition expenses, related party transactions (cited by CFOs) and prior year adjustments (both groups). In BFB (2000) it was apparent that APs tended to emphasise narrower compliance issues rather than those involving commercial judgement. Such a trend is not apparent in this study.

In response to RQ 2 for many specific issues the ACC's level of awareness is similar to the other respondent groups. It can be concluded that the ACC is, in general, satisfactorily performing their information search boundary role. However, there are several significant differences which do not have an obvious explanation. These may, at least in part, be attributable to the noise introduced by unmatched samples.

\subsection{Parties involved in interactions (RQ 3 and RQ 4(a))}

The questionnaire asked respondents to indicate, by means of four tick boxes, whether or not each of the following four key individuals/groups were involved in discussions: CFO, AP, ACC and AC. It is not only the presence/absence of each key party that is of interest, it is also the particular configuration of parties. Given this format, there are 16 possible combinations of responses for each financial reporting issue listed. If none of the four parties was involved, this means that there was no discussion in relation to that issue, leaving 15 combinations that indicate discussion occurred. If only one of the four parties was involved, this can be interpreted as meaning that discussions were held with parties outside the four listed (e.g. company management or directors other than the CFO and AC members, members of the audit team or audit firm other than the AP, other outside parties, such as legal advisors, partner from another audit firm, etc.).

Across all potential discussion issues, the combined sample reported 5,445 discussions. The parties involved in these discussions are shown in Table 5, which reports frequencies for the 15 combinations. The most common set of parties involved in 
discussions was all four (37\%), followed by the CFO / AP dyad (28\%). Detailed results by company size and audit firm tier are shown in the Appendix.

[Table 5 about here]

To facilitate further analysis of this data (Tables 6), we focussed on the two groupings of the reported combinations considered to be of the greatest interest. The groupings are as follows:

- No AC or ACC (both the full AC and the ACC left out, i.e. combinations 1, 2 and 5 shown in Table 5);

- Presence of ACC but absence of full AC in discussion (i.e. combinations 3, 6, 8 and 11)

[Table 6 about here]

Table 6 shows, for each financial reporting issue included on the questionnaire, the percentage of discussions occurring for both key groupings for the combined sample. The 32 issues are organised into four issue categories: consolidation matters; primary statement issues; other accounting issues; and compliance and regulation. To provide context, the final column shows the incidence of discussions. Thus, for the first issue, $63.3 \%$ of respondents reported awareness of a discussion regarding issues in subsidiary undertakings; of these discussions, 39.7\% did not involve either the AC or ACC and 7.0\% involved the ACC but not the full AC. The final two rows of Table 6 show the number and percentage aggregated across all issues.

It can be seen that $35.3 \%$ of discussions do not involve either the AC or the ACC, indicating a lack of any active AC engagement in over one-third of interactions. Thus, boundary-spanning involvement in either or both of the roles of external representation and information search and processing is absent at both the individual and team levels. We suggest that ACCs may perform an information processing role in relation to themselves, by filtering out issues where they elect not to become involved. This may be because they recognise that their time available for AC activities is limited and therefore must be rationed. Rationing will most affect issues where the ACC believes that they do not have superior technical or business knowledge to the CFO / AP dyad 
and which are successfully resolved by this dyad. Such issues are unlikely to result in AC engagement due to the gatekeeping role of the ACC.

This $35.3 \%$ level of AC/ACC non-engagement is markedly higher than the $25 \%$ nonengagement of AC/ACC in audit-related issues in the Beattie et al. (2012) study. This may be because the various audit-related roles and responsibilities of the AC are detailed explicitly, whereas the responsibilities in relation to financial reporting issues are mentioned more generically. Moving on to distinguish the individual ACC from the full ACC, $6.0 \%$ of interactions involve the ACC but not the AC. This is consistent with the view that ACCs perform, in a significant minority of interactions, an individual information processing (gatekeeping) boundary role (Marrone 2010) with respect to the AC, blocking, filtering, transmitting or summarising information as they see fit. This is a lower level than found by Beattie et al. (2012) for audit-related issues (6\% c.f. 11\%). In response to RQ 3 (a) and (b) the evidence suggests that the AC and ACC are not fully engaged in discussions on all aspects of financial reporting decision-making. However, given that the ACCs' level of awareness of interactions is broadly the same as that of the other groups, it may be inferred that, while ACCs want to be kept informed, they do not expect to be routinely involved in decision making. This is consistent with the findings from the case studies within BFH (2011). The lack of ACC and AC involvement also suggests that an AC or an ACC may, rather than engaging in active decision-making, fulfil a passive ceremonial type role (Turley and Zaman 2007) and review and approve an issue without any discussion or questioning.

Turning to the detail in Table 6, a number of observations can be made from inspection of this table. The issues which are most likely to involve the ACC but not the AC are 'requirements of listing rules prescribed by the FSA', 'matters arising from compliance with the Companies Act and other accounting standards', 'statements in the annual report concerning compliance with the Combined Code', 'exceptional items' and 'fair value on acquisition' (each with a percentage between 9.0\% and 9.6\%). The ACC is often the member of the AC with recent and relevant financial experience and might be expected to deal with narrow issues of compliance where other members of the AC with broader business knowledge might have less to contribute. The first three of these issues are from the 'compliance and regulatory issues' section of the questionnaire and would 
appear to fit this description, although it might be expected that the full AC should be concerned with how corporate governance activities are reported.

The two issues for which discussions are most likely to exclude both the ACC and AC are consolidation matters. However the matters concerned ('dividends from subsidiaries' and 'identification of pre/post acquisition expenses') are relatively uncontroversial. There is no obvious pattern for the other issues where AC / ACC are involved less frequently. At the other end of the scale it is not surprising that they are least likely to excluded from discussions about 'fraud and illegal acts', 'going concern' and 'statements in the annual report concerning compliance with the Combined Code' as these cover fundamental AC responsibilities. In response to RQ 4(a), it would appear that the nature of the financial reporting issue does have an impact on the parties involved in interactions. The absence of any full AC or ACC involvement ranges from 62\% (dividends from subsidiaries) down to $17 \%$ (fraud and illegal acts).

Further analysis revealed that the parties involved reported, as reported by ACC respondents, are significantly different from those reported by the other two respondent groups. The ACCs report significantly fewer discussions than the CFOs or APs where neither they nor the full AC is involved (21\%, $45 \%$ and $38 \%$, respectively; $\chi^{2}=209.5$, sig $<0.01$ ). They also report more interactions where the ACC but not the full AC is involved $\left(9 \%, 5 \%\right.$ and $5 \%$, respectively; $\chi^{2}=26.4$, sig $\left.<0.01\right)$. Given that the ACCs reported substantially the same number of discussions as the other two groups (see Table 3 , row 1), this does seem to suggest that the perceptions/recollections of parties involved varies across the respondent groups rather than there being discussions of which the ACC is simply unaware. Previous research into the reported level of issue negotiation by APs and CFOs has found that APs report a higher level, attributing this to the relatively higher incentives of APs to recall and declare such interactions (Beattie et al. 2000, p.199). Similarly, ACCs are likely to be more sensitive than either APs or CFOs to their explicit responsibility in relation to significant accounting issues, causing them to report higher levels of engagement. Another (not mutually exclusive) explanation is that, despite the large sample sizes, the findings reflect random noise rather than a systematic effect. The unmatched nature of the samples exacerbates the noise in the data. 


\subsection{Influences on parties involved (RQ 4(b) and (c))}

The relationship between the incidence of particular groupings and the background characteristics of company size and audit firm size is examined in Table 7, panels (a) and (b), respectively. While it is well-established that there is a strong positive correlation between company size and audit firm size (Moizer and Turley 1987, p.120), both variables are examined since distinct organisational practices (company-side or audit firm-side) can influence the parties involved in discussions.

In addition to the two groupings shown in Table 6, five other groupings are presented as follows:

- No AC or ACC (both the full AC and the ACC left out, i.e. combinations 1, 2 and 5 shown in Table 5);

- ACC but no AC (combinations 3, 6, 8 and 11);

- No AP or AC (both the AP and the full AC left out, i.e. combinations 1, 3 and 6);

- $\quad$ No CFO (the CFO is left out, i.e. combinations 2, 3, 4, 8, 9, 10 and 14);

- All in (none of the four key parties is left out, with ACC acting either as part of the full AC or separately from it as an individual, i.e. combinations 12 and 15);

- No AC (the full AC is left out, i.e. combinations 1, 2, 3, 5, 6, 8 and 11); and

- No AP (the AP left out, i.e. combinations 1, 3, 4, 6, 7, 10 and 13).

[Table 7 about here]

Panel (a), concerned with company size (proxied by the dichotomous variable FTSE 350 member), shows significant results across all seven groupings. FTSE 350 affiliated respondents were more likely to report 'All in' and (curiously) 'No CFO' and less likely to report instances of the other five groupings. Conversely non-FTSE 350 companies were significantly more likely to report that the AC or both the ACC and AC were not involved in an interaction. The incidence of 'ACC but no AC' is 4.7\% in FTSE 350 companies compared with $8.5 \%$ in non-FTSE 350 companies. This would appear to indicate that ACCs in smaller companies interpret their boundary filtering role with respect to the AC differently. They may be more sceptical about the extent to which the rest of the AC can contribute effectively to a discussion of financial reporting issues or it may mean that processes are more informal and that more matters are settled outside of committee meetings (Turley and Zaman 2007). A further interpretation might be that in 
smaller companies, the ACC may become involved in discussions as an additional source of financial reporting expertise. In response to RQ 4(b), it would appear that company size influences the nature of the boundary filtering role and, consequently, has an effect on the parties involved in an interaction.

Finally, panel (b), concerned with audit firm size, does not reveal many significant differences. Big Four affiliated respondents (i.e. Big Four APs or the CFOs or ACCs of companies with a Big Four auditor) were significantly more likely to report 'All in' and less likely to report 'ACC but no AC' or 'No AC'. Of course, the auditor tier and company size measures are likely to be highly correlated, as large companies tend to select large audit firms (Moizer and Turley 1987). Regarding RQ 4 (c) it would appear that audit firm size will have, at most, a marginal impact on who is involved in an interaction.

\section{CONCLUSIONS}

Post-financial crisis, and building on the provisions of SOX, actual and proposed regulatory reforms focus on extending $\mathrm{AC}$ engagement as a means to improve the quality of financial reporting (EC 2011, §23, Competition Commission 2013, FRC 2012). Although ACs are widely acknowledged as a key corporate governance mechanism, very little is known about their engagement in the process by which the financial statements are co-constituted by the actors affiliated to the auditee company and the audit firm. Previous questionnaire studies have focussed only on the CFO / AP dyad (Beattie et al. 2000, Gibbins et al. 2007). The present study complements the limited extant case study research on the CFO / AP / AC triad (Beattie et al. 2011, Salleh and Stewart 2012) by providing large sample evidence that can be generalised to the population of interest. This population comprises listed companies operating in post-IFRS adoption, post-SOX, Anglo-Saxon corporate governance environments. This evidence reveals how crucial existing AC responsibilities are being discharged, offering a valuable baseline for future academic research and policy-making.

By means of an experiential questionnaire survey of the three principal parties in the financial reporting interaction process (CFOs, APs and ACCs), the nature and extent of engagement of AC in financial reporting issues is investigated. AC engagement in these interactions is conceived as a two-stage process comprising awareness and involvement. 
The ACC (and the AC) are viewed as fulfilling the role of boundary spanners, a theoretical construct drawn from the organisational studies literature. Moreover, the ACC fulfils an additional gatekeeping role with respect to the AC and the main board. AC effectiveness is a multidimensional construct and its evaluation is acknowledged to be difficult (Bédard and Gendron 2010). We contend that, in additional to investigating publicly observable AC dimensions such as meeting frequency, a dimension of central importance is $\mathrm{AC}$ engagement (i.e. awareness and involvement) on financial reporting issues. Following Beattie et al. (2012), the involvement of the ACC is considered separately from the full AC.

It is found that ACCs' overall level of awareness of discussions of financial reporting issues was comparable to that of CFOs and APs (the median number of issues is 10, 10 and 11, respectively). Their level of awareness of specific issues was also broadly in line with CFOs and APs (there was no significant difference for $75 \%$ of the issues). For those eight issues where a significant difference did exist, no systematic explanation was apparent. One surprise was that ACCs were significantly less likely than APs to be aware of discussions on fraud and illegal acts, given that they are charged with specific responsibilities in this area under the UK Corporate Governance Code (FRC 2006b). This is of particular interest as it is also an internal control and risk-related matter of concern to the EC (2011).

Across 5,445 reported discussions, 35.3\% did not involve either the AC or the ACC, Thus, in over one-third of discussion, the AC fulfilled no boundary spanning role (in most of these cases, the interaction involved the traditional CFO / AP dyad. These findings indicate that neither the AC nor the ACC were fully engaged in all aspects of financial reporting decision-making. However it is clear from qualitative, case study evidence (BFH 2011) that ACCs do not expect to be involved in routine decision making. Fundamental financial reporting issues such as fraud and going concern were most likely to involve ACs and ACCs. The present study finds a markedly higher overall level of non-involvement of the AC in financial reporting interactions (35\%) compared to the Beattie et al. (2012) study's findings regarding non-involvement of the AC in audit-related tasks and responsibilities (25\%). This provides further evidence of partial engagement, supporting the conclusion of Beattie et al. (2012) regulators should be cautious about giving ACs additional responsibilities. 
The significant minority of cases (6.0\%) where the ACC but not the AC was involved reveal situations where the ACC acts as a boundary spanning gatekeeper to the full AC (Coffee 2006). These cases are indicative of informal AC processes, such as found in prior research (Gendron and Bédard 2006, Turley and Zaman 2007, BFH 2012). There was some evidence that ACCs were more likely to be involved without other members of the AC on compliance and regulatory issues. The significant lack of engagement by the AC is consistent with the findings of KPMG in relation to AC involvement in judgments and estimates (2010; 2013). ACC respondents reported significantly fewer discussions than the other two respondent groups where neither they nor the full AC was involved, suggesting that the perceptions/recollections of parties involved varied across the respondent groups (although the number of recalled discussions did not).

The relationship between the incidence of particular parties involved and background characteristics revealed several significant associations. Respondents affiliated with large listed companies were more likely to report 'All in' and, interestingly, 'No CFO'. The latter finding is, however, based on a very small number of instances. It is hard to believe that the CFO is not involved in all financial reporting issues. Non-FTSE 350 companies were more likely to report that ACCs acted without the rest of the AC. Big Four affiliated respondents were significantly more likely to report 'All in' and less likely to report either 'ACC but no AC' or 'No AC', but there were relatively few significant differences suggesting only a marginal impact.

The results indicate that not all financial reporting issues are dealt with in the same way and that discussions may involve different parties depending on the nature of the issue, the size of the company and to a lesser extent, the size of the audit firm. A substantial proportion of discussions of financial reporting issues do not involve the ACC as an individual separate from the AC and many do not involve the full AC. Given that the AC can be viewed as a boundary spanning group with a key role interceding between management and the AP, their absence from many discussions must be a potential cause for concern. BFH (2011) found a marked improvement in the quality of interaction outcomes compared with the earlier BFB (2001) case studies, conducted before ACs were given an enhanced role within the regulatory framework. The nature of this survey study does not permit investigation into the significance to the financial statements of the issues of which the various parties 
were aware, but did not discuss. It is possible that issues may be approved or agreed by the ACC or the AC without discussion. Another interpretation is that the AC exerted a passive role in encouraging APs and CFOs to resolve disputes between themselves (Cohen et al. 2010). Attachments that have formed between boundary spanners may have produced expectations of trust so that ACCs and ACs believe that CFOs and APs will generally act constructively rather than opportunistically (Seabright et al., 1992; Granovetter, 1985). If the attachment is at the organisational level, then the rotation of APs or the departure of other boundary spanners may not be significant (van de Ven, 1976). BFH (2011) found that, while ACCs were keen to be updated on problem areas to avoid surprises, they expected CFOs (with superior business knowledge) and APs (with superior technical accounting knowledge) to be able to resolve most issues between themselves. It is also possible that some financial reporting issues are very complex for an AC with possibly only one member with recent and relevant financial experience, although discussions on other issues might benefit from contributions from members with broader business experience (Cohen et al. 2008).

The less than full engagement by ACs and ACCs in financial reporting interactions revealed by this research will be of interest to regulators as they consider further developments to the role of ACs and ACCs following the financial crisis. The evidence of the ACC performing a gatekeeper role in relation to the full AC, particularly in smaller companies is a matter of concern if the distinction between management and monitoring becomes blurred and the independence of non-executive directors (NEDs) and the level of trust associated with them (Perrone et al. 2003) is brought into question. The absence of engagement by either the ACC or the AC in slightly over one third of financial reporting discussion interactions suggests that caution should be exercised by regulators in expecting too much of an ACC and AC in financial reporting matters. While passive 'awareness' may be adequate in relation to some issues, the finding that in $17.2 \%$ of discussions about fraud and illegal acts neither the ACC nor the AC is involved does give cause for concern. This issue is a named responsibility of the AC in the Combined Code where active involvement would be expected. The findings also raise the question of whether one set of regulations is appropriate and practical for companies of all sizes, or whether FTSE 350 companies should be considered separately. 
There are other potential dangers in extending the responsibilities of ACs and ACCs. Perrone et al. (2003) argue that formal role definitions are not good predictors of trust and that only when boundary spanners exercise discretion does this provide information about their trustworthiness. If the opportunities to exercise discretion are curtailed by extending the scope of codes that formally define their roles, it becomes more difficult for external parties to ascertain the motivations and trustworthiness of individuals. This becomes pertinent when they need to deal with unplanned contingencies and move outside of the strict specifications of the role and may potentially impact on external legitimacy. This resonates with BFH (2011) who found that in a strong compliance culture the highest quality financial reporting outcomes were no longer achievable.

Bezemer et al. (2007) argue that corporate governance codes have tended to increase the control and internal service tasks (i.e. acting as advisers and counsellors to executive directors) of non-executive directors, leaving them less time for their external representation boundary spanning role which focuses on value created through relationships and acquiring access to resources. They suggest that any further shift in this direction may change the selection criteria for NEDS, so that individuals with networking skills, able to add value and external legitimacy are overlooked in favour of those able to demonstrate a cognitive fit with existing board members. The increasing demands made on the time of NEDs are likely to impact adversely on their recruitment. FTSE 350 companies are likely to find it easier than smaller companies to appoint ACs composed of individuals with appropriate expertise and qualities to undertake the increasingly onerous responsibilities. Interestingly, the EC (2011) is proposing that one member of the AC should have auditing experience and another should have either auditing or financial reporting experience, thus increasing the requirement for relevant expertise compared with the current UK regime.

As with all research the present study has inevitable limitations. In particular, the questionnaire approach brings response noise and potential response biases. However, these risks are mitigated by the seniority of the respondents (minimal risk of uninformed respondent bias) and the relatively high response rate obtained. In terms of further research, the growing focus on the contribution of ACs and ACCs to the integrity of financial reporting is a key area of research. Future studies of the antecedents and consequences of different configurations of the parties involved (i.e. different 
engagement patterns), would contribute greatly to knowledge. Possible antecedents exist at the level of the individual, group (AC team) and organisation and may be contingent upon the nature of the financial statement issue. A particularly interesting issue is whether the level of engagement of an AC or ACC on financial reporting issues can be related to earnings management or other observable proxies for poor quality accounting outcomes. It would be of interest to explore the role of other individuals and groups beyond the CFO / AP / AC triad (such as the CEO, main board, audit review partner, technical departments). However it should be noted that, while executive directors may attend AC meetings, the revised grounded theory model of audit interactions developed by BFH (2011) finds that the influence of company context (including main board influence) is fairly marginal in the changed regulatory context. There is also a need for rich, qualitative case studies, building on BFH (2011), which elicit more information about how ACs and ACCs engage with financial reporting and perform their individual and team boundary spanning roles. Potentially relevant individual processes which may be explored include social influence, norms of reciprocity, and social identity (Westphal and Zajac 2013), and potentially relevant group processes include leadership, norms, trust, group cohesion, group potency and group identity (Brown 2000). 


\section{NOTES}

${ }^{1}$ Neither the 2008 nor the 2010 revisions to the Corporate Governance Code (FRC 2008, 2010) materially changed the requirements for audit committees in relation to financial reporting in comparison with 2007. Changes introduced in the aftermath of the financial crisis into the 2012 revision require companies (for accounting periods beginning on or after 1 October 2012) to include in a separate section of the annual report a description of 'the significant issues that [the audit committee] considered in relation to the financial statements, and how these issues were addressed (FRC 2012, para. C.3.8).

${ }^{2}$ In 2005 the UK adopted International Auditing Standards with some adjustments to ensure compliance with UK company law.

${ }^{3}$ Furthermore, the usual code requirement that the AC should include at least one person with recent and relevant financial experience could be viewed as a resource for smaller companies with smaller finance functions.

${ }^{4}$ It is noted that other actors also fulfil boundary spanning roles, however the focus of the present study is the AC.

${ }^{5}$ Representative UK studies include Song and Windram (2004) and Al Najjar (2011); Piot and Janin (2007) consider France; Pucheta-Martínez and de Fuentes (2007) consider Spain.

${ }^{6}$ While the mean reported incidence of discussions was found to be broadly similar across the three respondent groups, $11 \%$ of discussions involve the ACC only, rather than the full AC, and a further $25 \%$ do not involve any member of the AC.

${ }^{7}$ Four weeks prior to mailing the questionnaire, the names and addresses of companies, CFOs and ACCs were checked and where necessary corrected using Regulatory News Service data (which requires prompt announcement of changes in board and directorate membership).

${ }^{8 .}$ A fifth group of 2 Sarbanes-Oxley Act issues and one item relating to regulated industries are excluded from the present paper as they do not apply to all companies.

9. BFB (2000) used a longer three year period to ensure that some negotiation activity was picked up by the questionnaire. In the present study, a single year was used as, based on the evidence in BFB, this would generate sufficient levels of negotiation to be informative and to avoid straddling pre- and post IFRS implementation.

10. ACC respondents were all audit committee chairs, with the exception of two who were Deputy Chairs; AP respondents were all listed company audit engagement partners (4 responses were eliminated as they did not fall within the criteria set for the following reasons: client reported under US GAAP only, client not yet on IFRS (AIM company), AP audited investment trusts only; and client was a public sector organisation); CFO respondents, based on job title, were FD/Group FD/CFO (74\%), financial controller (9\%), (group) chief accountant (3\%), deputy FD (1\%) and other/non stated (13\%). 


\section{REFERENCES}

Aldrich, H. and Herker, D., 1977. Boundary spanning roles and organization structure. Academy of Management Review, 2 (2), 217-230.

Al-Najjar, B., 2011. The determinants of audit committee independence and activity: evidence from the UK. International Journal of Auditing, 15(2), 191-203.

APB, 2004. ISA (UK and Ireland) 260. Communication of audit matters with those charged with governance, International Standard on Auditing (UK and Ireland) 260. London: Auditing Practices Board.

AIU, 2008. Audit Quality Inspection: An Overview. Audit Inspection Unit, London: FRC.

AIU, 2010. 2009/10 AIU Annual Report. Audit Inspection Unit, London: FRC.

Barratt, R. and Korac Kakabadse, N., 2002. Developing reflexive corporate leadership: The role of the non-executive director. Corporate Governance, 2 (3), 32-36.

Beasley, M.S., Carcello, J.V., Hermanson, D.R. and Neal, T.L., 2009. The audit committee oversight process. Contemporary Accounting Research, 26 (1), 65-122.

Beattie, V. A, Fearnley, S. and Brandt, R., 2000. Behind the audit report: A descriptive study of discussion and negotiation between auditors and directors, International Journal of Auditing, 4(2), 177-202.

Beattie, V.A., Fearnley, S. and Brandt, R., 2001. Behind Closed Doors: What Company Audit is Really About. Basingstoke: Palgrave.

Beattie, V. A., Fearnley, S. and Hines, T., 2011. Reaching Key Financial Reporting Decisions: How UK Directors and Auditors Interact. Chichester: John Wiley \& Sons.

Beattie, V. A., Fearnley, S. and Hines, T., 2012. Do audit committees really engage with auditors on planning and performance? Accounting \& Business Research, 42 (3), 349-375.

Bédard, J. and Gendron, Y., 2010. Strengthening the financial reporting system: can audit committees deliver? International Journal of Auditing, 14 (2), 174-210.

Bezemer, P., Maassen, G.F., Van den Bosch, F.A. J. and Volberda, H. W., 2007. Investigating the development of the internal and external service tasks of nonexecutive directors: the case of the Netherlands (1997-2005). Corporate Governance, 15 (6), 1119-1129.

Böhm, F., Bollen, L. H. and Hassink, H. F., 2012. Spotlight on the design of European audit committees: A comparative descriptive study. International Journal of Auditing, 17 (2), 138-161 (doi:10.1111/j.1099-1123.2012.00461.x). 
Brown, R. 2000. Group Processes. $2^{\text {nd }}$ ed. Oxford: Blackwell Publishing.

Buijink, W., 2006. Evidence-based financial reporting regulation. Abacus, 42(3/4), 296-301.

Cadbury Report, 1992. Report of the Committee on the Financial Aspects of Corporate Governance. London: Gee and Co.

Carcello, J.V., Hermanson, D.R. and Ye, Z., 2011. Corporate governance research in accounting and auditing: insights, practice implications, and future research directions. Auditing: A Journal of Practice and Theory, 30 (3), 1-31.

Cicon, J.E., Ferris, S.P., Kammel, A.J. and Noronha, G., 2012. European corporate governance: a thematic analysis of national codes of governance. European Financial Management, 18 (4), 620-648.

Clarke, T., 2011. The globalisation of corporate governance? Irresistible markets meet immovable institutions. In: A. Brink, ed. Corporate Governance and Business Ethics. Dordrecht Heidelberg London New York: Springer.

Coffee, J.C., 2006. Gatekeepers: The Professions and Corporate Governance. Oxford, UK: Oxford University Press.

Cohen, J., Krishnamoorthy, G. and Wright, A.M., 2002. Corporate governance and the audit process. Contemporary Accounting Research, 19 (4), 573-594.

Cohen, J., Krishnamoorthy, G. and Wright, A. M., 2008. Form versus substance: The implications for auditing practice and research of alternative perspectives on corporate governance. Auditing: A Journal of Practice and Theory, 27 (2), 181198.

Cohen, J., Krishnamoorthy, G. and Wright, A., 2010. Corporate governance in the post Sarbanes-Oxley era: Auditors' experiences. Contemporary Accounting Research, 27 (3), 751-786.

Collier, P. and Zaman, M., 2005. Convergence in European corporate governance: the audit committee concept. Corporate Governance, 13 (6), 753-768.

Competition Commission, 2013. Statutory Audit Services for Large Companies Market Investigation: A Report on the Provision of Statutory Audit Services to Large Companies in the UK. Available from: http://www.competitioncommission.org.uk/assets/competitioncommission/docs/2011/statutory-auditservices/131016_final_report.pdf [Accessed 4 December 2013].

Davies, M. and Schlitzer, B., 2008. The impracticality of an international 'one size fits all' corporate governance code of best practice. Managerial Auditing Journal, 23 (6), 532-544.

Deloitte, 2011. Gems and Jetsam: Surveying Annual Reports. London: Deloitte. 
DeZoort, F.T., Hermanson, D.R. and Houston, R.W., 2003. Audit committee member support for proposed audit adjustments: A source credibility perspective. Auditing: A Journal of Practice and Theory, 22 (2), 189-205.

DeZoort, F.T., Hermanson, D.R. and Houston, R.W., 2008. Audit committee member support for proposed audit adjustments: Pre-SOX versus post-SOX judgments. Auditing: A Journal of Practice and Theory, 27 (1), 85-105.

EC, 2011. Proposal for a Regulation of the European Parliament and of the Council: on specific requirements regarding statutory audit of public interest entities. Brussels. COM (2011) 779/3. 2011/0359(COD). European Commission: Brussels.

FEE, 2012. The Functioning of Audit Committees, Discussion Paper. Federation of European Accountants. Available from: http://www.fee. be/index.php?option= com_content\&view= article\&id= 519 \&ltemid= 106\&lang= en [Accessed 24 March 2013]

Francis, J.R., 2004. What do we know about audit quality? British Accounting Review, 36 (4), 345-368.

FRC, 2006a. The UK Approach to Corporate Governance. London: Financial Reporting Council.

FRC, 2006b. The Combined Code on Corporate Governance London: Financial Reporting Council.

FRC, 2008. The Combined Code on Corporate Governance London: Financial Reporting Council.

FRC, 2010. The UK Corporate Governance Code London: Financial Reporting Council.

FRC, 2012. The UK Corporate Governance Code. London: Financial Reporting Council. Available from: http://frc.org.uk/Our-Work/Publications/CorporateGovernance/UK-Corporate-Governance-Code-September-2012.aspx [Accessed 24 May 2013].

García-Castro, R., Aguilera, R.V. and Ariño, M.A., 2013. Bundles of firm corporate governance practices: a fuzzy set analysis. Corporate Governance: An International Review, 21 (4), 390-407.

Gendron, Y. and Bédard, J., 2006. On the constitution of audit committee effectiveness. Accounting, Organizations and Society, 31 (3), 211-239.

Gibbins, M, McCracken, S.A. and Salterio, S.E., 2007. The Chief Financial Officer’s perspective on auditor-client negotiations. Contemporary Accounting Research, 24 (2), 387-422

Gibbins, M. and Qu, S.Q., 2005. Eliciting experts’ context knowledge with theory-based experiential questionnaires. Behavioral Research in Accounting, 17, 71-88. 
Granovetter, M., 1985. Economic action and social structure: The problem of embeddedness. American Journal of Sociology, 91, 481-510.

Haka, S. and Chalos, P., 1990. Evidence of agency conflict among management, auditors, and the audit committee chair. Journal of Accounting and Public Policy, 9 (4), 271-292.

Hillman, A. J. and Dalziel, T., 2003. Boards of directors and firm performance: Integrating agency and resource dependence perspectives. Academy of Management Review, 28 (3), 383-396.

ICAEW, 2006. Effective Corporate Governance Frameworks. London: Institute of Chartered Accountants in England and Wales.

ICAEW / BDO, 2011. The Buck Stops Here? New Challenges for Audit Committees London: Institute of Chartered Accountants in England and Wales.

Jensen, M. and Meckling, W., 1976. Theory of the firm: Managerial behaviour, agency costs and ownership structure. Journal of Financial Economics, 3 (4), 305-360.

KPMG, 2006. The Audit Committee Journey: A Global View 2005-6. London: KPMG.

KPMG, 2010. International Survey of Audit Committee Members. Available from: http://www. kpmg. com. au/aci/docs/ACl-2010-Int-Aud-Committee-MemberSurvey.pdf

KPMG, 2013a Global Audit Committee Survey, Available from: http://www.kpmg.co.uk/pubs/Final-A4-web-global-aci-survey-2013.pdf

KPMG, 2013b. The ACl Chair 100 Group: Summary of Discussions - Dialogue with Investors on Audit Committee Reporting and Audit Issues. Audit Committee Institute. Available from: http://www.kpmg.co.uk/pubs/280322_ACI_CHAIR_100_GROUP_acc.pdf

Kumar, P. and Zattoni, A., 2013. Editorial. How much do country-level or firmlevel variables matter in corporate governance studies? Corporate Governance: An International Review, 21 (3), 199-200.

La Porta, R., Lopez-de-Silanes, F. and Shleifer, A., 2008. The economic consequences of legal origins. Journal of Economic Literature, 46 (2), 285332.

Leuz, C., 2010. Different approaches to corporate reporting regulation: how jurisdictions differ and why. Accounting and Business Research, 40 (3), 229256.

Lin, J.W. and Hwang, M.I., 2010. Audit quality, corporate governance, and earnings management: a meta-analysis. International Journal of Auditing, 14 (1), 5777.

Marrone, J.A., 2010. Team boundary spanning: a multilevel review of past research and proposals for the future. Journal of Management, 36 (4), 911-940. 
Moizer, P. and Turley, S., 1987. Surrogates for audit fees in concentration studies. Auditing: A Journal of Practice and Theory, 7 (1), 118-123.

Nelson, M. and Tan, H-T., 2005. Judgment and decision making research in auditing: A task, person, and interpersonal interaction perspective. Auditing: A Journal of Practice and Theory, 24 (Supplement), 41-71.

Oxley, M.G., 2007. The Sarbanes-Oxley Act of 2002 - Restoring investor confidence. Current Issues in Auditing, 1(1): C1-C2.

Perrone, V., Zaheer, A. and McEvily, B., 2003. Free to be trusted? Organizational constraints on trust in boundary spanners. Organizational Science, 14 (4), 422439.

Piot, C. and Janin, R., 2007. External auditors, audit committees and earnings management in France. European Accounting Review, 16 (2), 429-454.

Pucheta-Martínez, M. C. and de Fuentes, C., 2007. The impact of audit committee characteristics on the enhancement of the quality of financial reporting: an empirical study in the Spanish context. Corporate Governance: An International Review, 15 (6), 1394-1412.

Quick, R., Turley, S. and Willekens, M., 2007. Auditing, Trust and Governance: Developing Regulation in Europe. Oxford: Routledge.

Rupley, K., Almer, E. and Philbrick, D., 2011. Audit committee effectiveness: perceptions of public company audit committee members post-SOX. Research in Accounting Regulation, 23 (2), 138-144.

Sabia, M.J. and Goodfellow, J.L., 2005. Integrity in the Spotlight: Audit Committees in a High Risk World. $2^{\text {nd }}$ ed. Toronto, Ontario: Canadian Institute of Chartered Accountants.

Salleh, Z. and Stewart, J., 2012. The role of the audit committee in resolving auditorclient disagreements: A Malaysian study. Accounting, Auditing and Accountability Journal, 25 (8), 1340-1372.

Salterio, S.E., 2012. Fifteen years in the trenches: auditor-client negotiations exposed and explored. Accounting and Finance, 52 (Supplement), 233-286.

Sarbanes-Oxley Act, 2002. Available from: http://taft.law.uc.edu/CCL/SOact/soact.pdf. [Accessed 3 October 2011].

Seabright, M. A., Levinthal, D. A. and Fichman, M., 1992. Role of individual attachments in the dissolution of interorganizational relationships. Academy of Management Journal, 35 (1), 122-160.

Smith Committee, 2003. Audit Committee Combined Code Guidance. London: Financial Reporting Council. 
Song, J. and Windram, B., 2004. Benchmarking audit committee effectiveness in financial reporting. International Journal of Auditing, 8 (3), 195-205.

Spira, L., 1999. Ceremonies of governance: perspectives on the role of the audit committee. Journal of Management and Governance, 3 (3), 231-260.

Turley, S., 2007. Developments in the framework of auditing regulation in the United Kingdom. In: R. Quick, S. Turley and M. Willekens, eds. Auditing, Trust and Governance: Developing Regulation in Europe. Oxford: Routledge, 205-222.

Turley, S. and Zaman, M., 2007. Audit committee effectiveness: processes and behavioural effects. Accounting, Auditing and Accountability Journal, 20 (5), 765-768.

van de Ven, A. H., 1976. On the nature, formation, and maintenance of relations among organizations. Academy of Management Review, 1 (4), 24-36.

van Essen, M., Engelen, P.-J. and Carney, M., 2013. Does "good" corporate governance help in a crisis? The impact of country- and firm-level governance mechanisms in the European financial crisis. Corporate Governance: An International Review, 21 (3), 201-224.

Westphal, J.D. and Zajac, E.J., 2013. A behavioral theory of corporate governance: explicating the mechanisms of socially situated and socially constituted agency. Academy of Management Review Annals, 7 (1), 605659.

Williams, P., 2002. The competent boundary spanner. Public Administration, 80 (1), 103-124. 


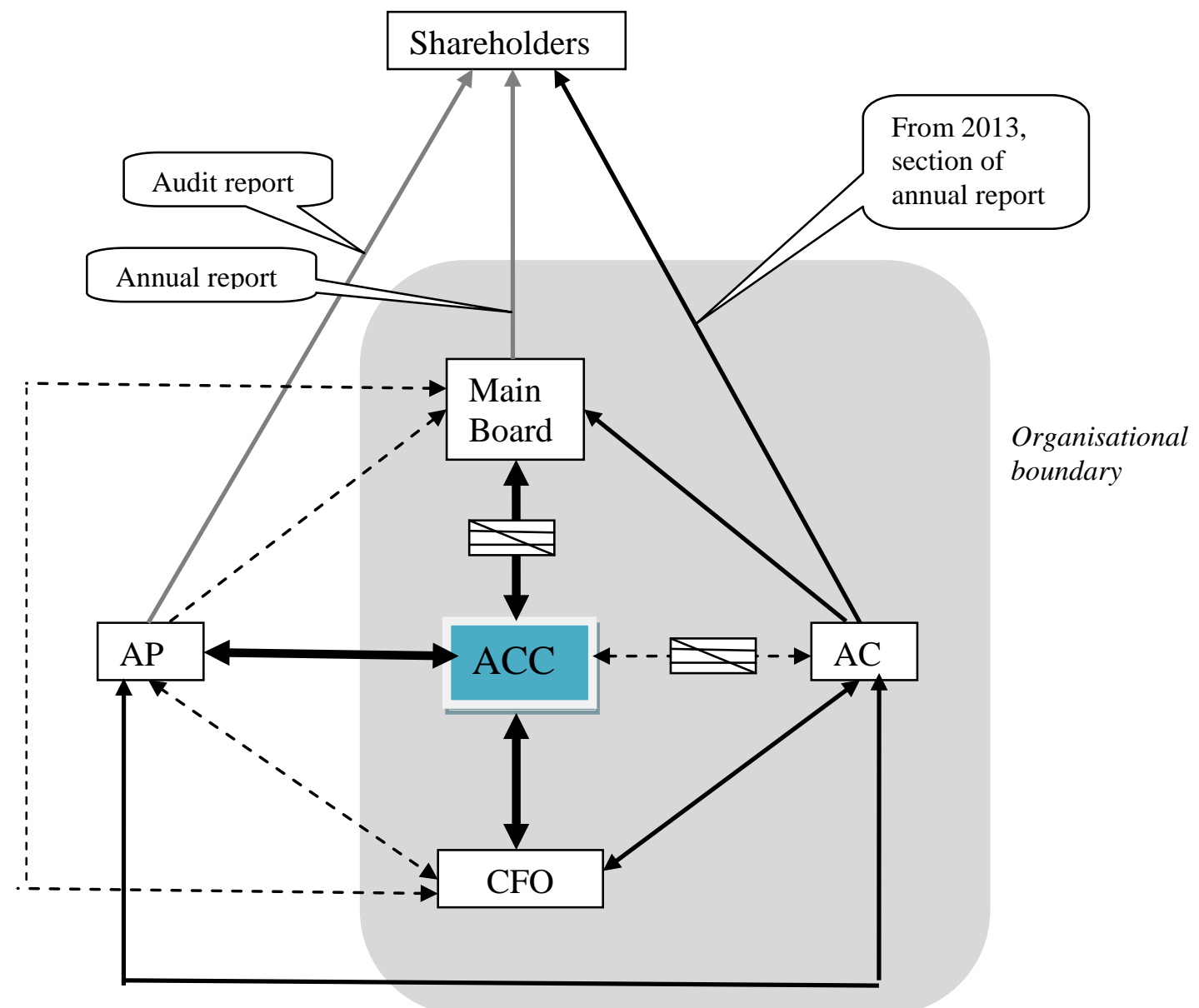

\section{Notes to figure:}

1. $\mathrm{AC}=$ audit committee; $\mathrm{ACC}=$ audit committee chair; $\mathrm{CFO}=$ finance director; $\mathrm{AP}=$ audit partner.

2. Very thick solid black lines denote individual-level boundary spanning by the ACC.

3. Thick solid black lines denote team boundary spanning by the AC and may include formal corporate governance reporting responsibilities (reporting as a sub-committee to the main board and, from 2013, to the shareholders via a separate section of the corporate annual report).

4. Thick solid grey lines denote formal corporate governance responsibilities.

5. Thin dashed lines represent other relationships.

6. denotes gatekeeping role. 
Table 1: Listing of issues in the questionnaire instrument

No. Consolidation matters (C)

1 Issues in subsidiary undertakings ${ }^{1}$

2 Issues in associates or joint ventures ${ }^{1}$

3 Fair value on acquisition ${ }^{1}$

Identification of pre/post acquisition expenses $^{1}$

$5 \quad$ Dividends from subsidiaries ${ }^{3}$

$6 \quad$ Segmental reporting ${ }^{3}$

Other (please specify)

Primary statement issues (PS)

$7 \quad$ Revenue recognition ${ }^{1}$

8 Exceptional items ${ }^{2}$

$9 \quad$ Share based payments ${ }^{3}$

10 Retirement or other employee benefits

(e.g. pension schemes) ${ }^{2}$

11 Property, plant and equipment ${ }^{2}$

12 Leases $^{1}$

13 Intangible assets / goodwill ${ }^{2}$

14 Financial instruments ${ }^{3}$

15 Inventories ${ }^{2}$

16 Liabilities/provisions ${ }^{1}$

17 Contingent assets and liabilities ${ }^{2}$

18 Deferred tax assets / liabilities ${ }^{1}$

19 Equity / debt classification ${ }^{3}$

Other (please specify)

\section{Other accounting issues (OA)}

Presentation of the primary financial statements ${ }^{3}$

21 Post balance sheet events ${ }^{1}$

22 Prior year adjustments ${ }^{1}$

23 Related party transactions ${ }^{1}$

24 Going concern ${ }^{1}$

25 Fraud and illegal acts ${ }^{1}$

26 Business Review ${ }^{3}$

27 Substance over form / true and fair view issues $^{2}$ (please specify)

Other (please specify)

Notes:

1. Issue included in Beattie, Fearnley and Brandt (2000) (BFB) study.

2. Issue adapted from BFB study (e.g. broadened, issues combined or terminology updated to IFRS).

3. New issue; not included in BFB study.
No. Compliance and other regulatory issues (C\&R)

28 Maintenance of proper accounting records ${ }^{1}$

29 Directors' remuneration report ${ }^{2}$

30 Statements in the annual report concerning compliance with the Combined Code on Corporate Governance $^{2}$ (please specify)

Matters arising from compliance with the Companies Acts and accounting standards not covered above $^{1}$ (please specify)

Requirements of listing rules prescribed by the Financial Services Authority ${ }^{2}$ 
Table 2: Analysis of respondent groups by company size and audit firm size

Panel (a): Company Size (Stock Exchange Group)

\begin{tabular}{|l|r|r|r|r|r|r|}
\hline \multirow{2}{*}{$\begin{array}{l}\text { Stock Exchange } \\
\text { Group }\end{array}$} & \multicolumn{2}{|c|}{$\begin{array}{c}\text { Chief Financial } \\
\text { Officer (CFO) sample }\end{array}$} & \multicolumn{2}{c|}{$\begin{array}{c}\text { Audit Committee } \\
\text { Chair (ACC) sample }\end{array}$} & \multicolumn{2}{c|}{$\begin{array}{c}\text { Audit Partner } \\
\text { (AP) sample }\end{array}$} \\
\cline { 2 - 8 } & \multicolumn{1}{|c|}{ No. } & \multicolumn{1}{c|}{$\%$} & \multicolumn{1}{c|}{ No. } & \multicolumn{1}{c|}{$\%$} & \multicolumn{1}{c|}{ No. } & \multicolumn{1}{c|}{$\%$} \\
\hline FTSE 350 & 92 & 62.1 & 88 & 68.7 & 137 & 63.4 \\
\hline Non-FTSE 355 & 56 & 37.9 & 40 & 31.2 & 79 & 36.6 \\
\hline Missing & 1 & - & 2 & - & 3 & - \\
\hline Total & 149 & 100.0 & 130 & 100.0 & 219 & 100.0 \\
\hline
\end{tabular}

Panel (b): Audit Firm Size

\begin{tabular}{|l|r|r|r|r|r|r|}
\hline \multirow{2}{*}{ Audit firm type } & \multicolumn{2}{|c|}{$\begin{array}{c}\text { Chief Financial } \\
\text { Officer (CFO) sample }\end{array}$} & \multicolumn{2}{c|}{$\begin{array}{c}\text { Audit Committee } \\
\text { Chair (ACC) sample }\end{array}$} & \multicolumn{2}{c|}{$\begin{array}{c}\text { Audit Partmer } \\
\text { (AP) sample }\end{array}$} \\
\cline { 2 - 7 } & \multicolumn{1}{|c|}{ No. } & \multicolumn{1}{c|}{$\%$} & No. & \multicolumn{1}{c|}{$\%$} & \multicolumn{1}{c|}{ No. } & $\%$ \\
\hline Big four & 131 & 88.5 & 118 & 91.5 & 188 & 86.2 \\
\hline Non-big four & 17 & 11.5 & 11 & 8.5 & 30 & 13.8 \\
\hline Missing & 1 & - & 1 & - & 1 & - \\
\hline Total & 149 & 100.0 & 130 & 100.0 & 219 & 100.0 \\
\hline
\end{tabular}

Note to table:

Percentages are based on non-missing values. 
Table 3: Summary statistics of awareness of issues by group

\begin{tabular}{|l|r|r|r|r|r|r|r|r|r|r|}
\hline & \multicolumn{9}{c|}{ Number of issues cited: ${ }^{1}$} \\
\hline & \multicolumn{3}{|c|}{ Mean } & \multicolumn{3}{c|}{$\begin{array}{l}\text { Standard } \\
\text { deviation }\end{array}$} & \multicolumn{3}{c|}{ Median } \\
\hline & CFO & ACC & AP & CFO & ACC & AP & CFO & ACC & AP \\
\hline Discussion issues & 10.40 & 11.61 & 10.89 & 6.80 & 8.12 & 6.06 & 10 & 9.5 & 11 \\
\hline
\end{tabular}

Notes to table:

1. The maximum number of issues is 32 .

2. $\mathrm{ACC}=$ audit committee chair; $\mathrm{CFO}=$ finance director; $\mathrm{AP}=$ audit partner. 
Table 4: Infrequency of awareness of discussion of issues

\begin{tabular}{|c|c|c|c|c|c|c|c|c|}
\hline \multirow[b]{2}{*}{ Issue $^{1}$} & \multirow[b]{2}{*}{$\begin{array}{c}\text { Issue } \\
\text { category }^{2}\end{array}$} & \multicolumn{3}{|c|}{$\begin{array}{l}\% \text { indicating discussion } \\
\text { took place }^{3}(n=)\end{array}$} & \multicolumn{3}{|c|}{ Rank } & \multirow[t]{2}{*}{$\begin{array}{c}\text { ANOVA } \\
\text { test of } \\
\text { difference } \\
\text { between } \\
\text { groups } \\
\text { (prob.5 } \\
\end{array}$} \\
\hline & & $\begin{array}{l}\text { ACC } \\
(\mathbf{1 3 0 )}\end{array}$ & $\begin{array}{l}\text { CFO } \\
(149)\end{array}$ & $\begin{array}{c}\text { AP } \\
(219)\end{array}$ & CFO & ACC & AP & \\
\hline $\begin{array}{l}\text { Substance over form / true and fair view } \\
\text { issues }\end{array}$ & OA & 4.6 & 4.7 & 1.8 & 32 & 32 & 32 & NS \\
\hline $\begin{array}{l}\text { Matters arising from compliance with the } \\
\text { Companies Acts and accounting } \\
\text { standards not covered }\end{array}$ & C & 11.5 & 8.7 & 11.0 & $30=$ & 31 & 31 & NS \\
\hline Equity / debt classification & PS & 17.7 & 8.7 & 11.4 & $30=$ & 30 & 30 & NS \\
\hline Fraud and illegal acts & OA & 20.0 & 14.8 & 31.1 & 27 & $28=$ & 16 & $0.001^{3 \mathrm{e}, \mathrm{f}}$ \\
\hline $\begin{array}{l}\text { Requirements of listing rules prescribed } \\
\text { by the Financial Services Authority }\end{array}$ & $C \& R$ & 20.0 & 17.4 & 14.2 & $25=$ & $28=$ & 27 & NS \\
\hline Related party transactions & $\mathrm{OA}$ & 20.8 & 10.1 & 18.7 & 29 & 27 & $23=$ & $0.032^{3 \mathrm{~d}, \mathrm{e}}$ \\
\hline Dividends from subsidiaries & $\mathrm{C}$ & 22.3 & 17.4 & 14.6 & 23 & 26 & 26 & NS \\
\hline Maintenance of proper accounting records & $\mathrm{C} \& \mathrm{R}$ & 23.1 & 17.4 & 12.8 & $25=$ & 25 & $28=$ & $0.045^{3 c}$ \\
\hline Leases & PS & 24.6 & 18.1 & 16.9 & 24 & 24 & 25 & NS \\
\hline Property, plant and equipment & PS & 25.4 & 19.5 & 26.5 & 20 & 23 & $17=$ & NS \\
\hline Going concern & OA & 26.9 & 18.8 & 26.5 & $21=$ & 22 & $17=$ & NS \\
\hline $\begin{array}{l}\text { Identification of pre/post acquisition } \\
\text { expenses }\end{array}$ & C & 27.7 & 14.1 & 18.7 & 28 & $20=$ & $23=$ & $0.015^{3 \mathrm{~d}}$ \\
\hline Inventories & PS & 27.7 & 21.5 & 21.9 & 19 & $20=$ & 22 & NS \\
\hline Post balance sheet events & $\mathrm{OA}$ & 30.0 & 25.5 & 22.8 & 17 & 19 & $20=$ & NS \\
\hline Contingent assets and liabilities & PS & 32.3 & 24.8 & 26.5 & 18 & 18 & $17=$ & NS \\
\hline Prior year adjustments & $\mathrm{OA}$ & 33.1 & 18.8 & 12.8 & $21=$ & 17 & $28=$ & $0.000^{3 c, d}$ \\
\hline Issues in associates or joint ventures & $\mathrm{C}$ & 35.4 & 30.2 & 22.8 & 15 & 16 & $20=$ & $0.035^{3 \mathrm{c}}$ \\
\hline $\begin{array}{l}\text { Statements in the annual report } \\
\text { concerning compliance with the } \\
\text { Combined Code on Corporate } \\
\text { Governance }\end{array}$ & C\&R & 42.3 & 29.5 & 35.6 & 16 & $13=$ & 15 & NS \\
\hline Share based payments & PS & 42.3 & 44.3 & 54.8 & 12 & $13=$ & $5=$ & $0.038^{3 \mathrm{f}}$ \\
\hline $\begin{array}{l}\text { Retirement or other employee benefits } \\
\text { (e.g. pension schemes) }\end{array}$ & PS & 42.3 & 46.3 & 42.9 & 11 & $13=$ & 13 & NS \\
\hline Deferred tax assets / liabilities & PS & 43.8 & 56.4 & 51.1 & 4 & 12 & 9 & NS \\
\hline Directors' remuneration report & $\mathrm{C} \& \mathrm{R}$ & 45.4 & 37.6 & 40.6 & 14 & $10=$ & 14 & NS \\
\hline Financial instruments & PS & 45.4 & 38.9 & 43.4 & 13 & $10=$ & 12 & NS \\
\hline Segmental reporting & $\mathrm{C}$ & 49.2 & 57.7 & 54.8 & 3 & 9 & $5=$ & NS \\
\hline Issues in subsidiary undertakings & $\mathrm{C}$ & 53.1 & 61.1 & 71.2 & 2 & 8 & 1 & $0.002^{3 \mathrm{f}}$ \\
\hline Revenue recognition & PS & 53.8 & 53.0 & 54.3 & $7=$ & $6=$ & 7 & NS \\
\hline Business Review & $\mathrm{OA}$ & 53.8 & 55.7 & 55.3 & $5=$ & $6=$ & 4 & NS \\
\hline
\end{tabular}




\begin{tabular}{|c|c|c|c|c|c|c|c|c|}
\hline \multirow[b]{2}{*}{ Issue $^{1}$} & \multirow[b]{2}{*}{$\begin{array}{c}\text { Issue } \\
\text { category }^{2}\end{array}$} & \multicolumn{3}{|c|}{$\begin{array}{c}\% \text { indicating discussion } \\
\text { took place }^{3}(n=)\end{array}$} & \multicolumn{3}{|c|}{ Rank } & \multirow[t]{2}{*}{ 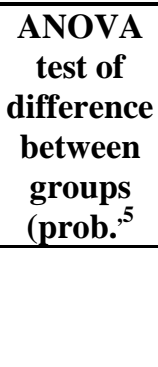 } \\
\hline & & $\begin{array}{l}\text { ACC } \\
\mathbf{( 1 3 0 )}\end{array}$ & $\begin{array}{l}\text { CFO } \\
(149) \\
\end{array}$ & $\begin{array}{c}\text { AP } \\
(219)\end{array}$ & CFO & ACC & AP & \\
\hline Liabilities/provisions & PS & 55.4 & 49.0 & 53.0 & $9=$ & 5 & 8 & NS \\
\hline Fair value on acquisition & $\mathrm{C}$ & 57.7 & 49.0 & 49.3 & $9=$ & $2=$ & $10=$ & NS \\
\hline Exceptional items & PS & 57.7 & 53.0 & 49.3 & $7=$ & $2=$ & $10=$ & NS \\
\hline $\begin{array}{l}\text { Presentation of the primary financial } \\
\text { statements }\end{array}$ & OA & 57.7 & 55.7 & 63.9 & $5=$ & $2=$ & 2 & NS \\
\hline Intangible assets / goodwill ${ }^{2}$ & PS & 58.5 & 62.4 & 59.4 & 1 & 1 & 3 & NS \\
\hline
\end{tabular}

Notes to table:

1. Issues are shown in increasing frequency for the ACC sample.

2. Consolidation matters (code C); primary statement issues (code PS); other accounting issues (code $\mathrm{OA}$ ); and compliance and other regulatory issues (code C\&R).

3. $\mathrm{ACC}=$ audit committee chair; $\mathrm{CFO}=$ finance director; $\mathrm{AP}=$ audit partner.

4. Issue which, based on ANOVA multiple comparison procedures (Tukey's HSD), is significantly (10\% level) more frequently cited:
a) by CFOs than ACCs;
b) by CFOs than APs;
c) by ACCs than APs
d) by ACCs than CFOs
e) by APs than CFOs
f) by APs than ACCs

5. NS = not significant at the $5 \%$ level. 
Table 5: Parties involved in discussions

\begin{tabular}{|l|r|r|r|}
\hline \multicolumn{1}{|c|}{ Parties involved $^{\mathbf{1}}$} & \multicolumn{3}{c|}{ Combined } \\
\hline & \multicolumn{1}{c|}{ No. } & \multicolumn{1}{c|}{$\%$} & Rank \\
\hline 1. CFO only & 355 & 6.5 & 4 \\
\hline 2. AP only & 32 & 0.6 & \\
\hline 3. ACC only & 5 & 0.1 & \\
\hline 4. AC only & 34 & 0.6 & \\
\hline 5. CFO + AP & 1536 & 28.2 & 2 \\
\hline 6. CFO + ACC & 52 & 1.0 & \\
\hline 7. CFO + AC & 155 & 2.9 & 6 \\
\hline 8. AP + ACC & 4 & 0.1 & \\
\hline 9. AP + AC & 35 & 0.6 & \\
\hline 10. ACC + AC & 4 & 0.1 & \\
\hline 11. CFO+AP+ACC & 266 & 4.9 & 5 \\
\hline 12. CFO+AP + AC & 836 & 15.4 & 3 \\
\hline 13. CFO+ACC+AC & 115 & 2.1 & 7 \\
\hline 14. AP + ACC +AC & 8 & 0.1 & \\
\hline 15. CFO+AP+ACC + AC & 2008 & 36.8 & 1 \\
\hline Total & $\mathbf{5 4 4 5}$ & $\mathbf{1 0 0 . 0}$ & \\
\hline
\end{tabular}

Notes to table:

1. $\mathrm{AC}=$ full audit committee; $\mathrm{ACC}=$ audit committee chair; $\mathrm{CFO}=$ finance director; $\mathrm{AP}=$ audit partner.

2. This combination includes the ACC acting as part of the full AC but not separately in an individual capacity 
Table 6: Incidence of lack of AC involvement in discussions of specific issues combined sample $(\mathbf{n}=498)$

\begin{tabular}{|c|c|c|c|}
\hline Issue & $\begin{array}{c}\text { Absence of any AC or } \\
\text { ACC involvement in } \\
\text { discussion } \\
\%\end{array}$ & $\begin{array}{l}\text { Presence of ACC but } \\
\text { Absence of full AC in } \\
\text { discussion }\end{array}$ & $\begin{array}{c}\text { Incidence of } \\
\text { discussion - combined } \\
\text { group } \\
\%\end{array}$ \\
\hline \multicolumn{4}{|l|}{ Consolidation matters } \\
\hline Issues in subsidiary undertakings & 39.7 & 7.0 & 63.3 \\
\hline Issues in associates or joint ventures & 41.8 & 4.3 & 28.3 \\
\hline Fair value on acquisition & 31.6 & 9.0 & 51.4 \\
\hline $\begin{array}{l}\text { Identification of pre/post acq'n } \\
\text { expenses }\end{array}$ & 56.1 & 3.1 & 19.7 \\
\hline Dividends from subsidiaries & 62.1 & 3.4 & 17.5 \\
\hline Segmental reporting & 44.4 & 7.0 & 54.2 \\
\hline \multicolumn{4}{|l|}{ Primary statement issues } \\
\hline Revenue recognition & 31.0 & 6.0 & 53.8 \\
\hline Exceptional items & 21.8 & 9.2 & 52.6 \\
\hline Share based payments & 44.0 & 4.6 & 48.4 \\
\hline Retirement or other employee benefits & 36.7 & 3.7 & 43.8 \\
\hline Property, plant and equipment & 46.7 & 4.2 & 24.1 \\
\hline Leases & 49.0 & 6.3 & 19.3 \\
\hline Intangible assets / goodwill & 22.7 & 6.0 & 60.0 \\
\hline Financial instruments & 37.3 & 3.3 & 42.6 \\
\hline Inventories & 38.8 & 4.3 & 23.3 \\
\hline Liabilities/provisions & 25.7 & 4.2 & 52.4 \\
\hline Contingent assets and liabilities & 29.2 & 3.6 & 27.5 \\
\hline Deferred tax assets / liabilities & 39.1 & 5.5 & 50.8 \\
\hline Equity / debt classification & 49.2 & 4.9 & 12.3 \\
\hline \multicolumn{4}{|l|}{ Other accounting issues } \\
\hline $\begin{array}{l}\text { Presentation of the primary fin'l } \\
\text { stmts }\end{array}$ & 35.2 & 7.0 & 59.8 \\
\hline Post balance sheet events & 43.3 & 4.7 & 25.5 \\
\hline Prior year adjustments & 28.3 & 7.1 & 19.9 \\
\hline Related party transactions & 49.4 & 2.4 & 16.7 \\
\hline Going concern & 20.7 & 5.8 & 24.3 \\
\hline Fraud and illegal acts & 17.2 & 6.0 & 23.3 \\
\hline Business Review & 32.1 & 5.1 & 55.0 \\
\hline $\begin{array}{l}\text { Substance over form / true and fair } \\
\text { view }\end{array}$ & 29.4 & 5.9 & 3.4 \\
\hline \multicolumn{4}{|l|}{ Compliance \& regulatory } \\
\hline $\begin{array}{l}\text { Maintenance of proper accounting } \\
\text { records }\end{array}$ & 40.5 & 6.0 & 16.8 \\
\hline Directors' remuneration report & 38.9 & 8.9 & 40.8 \\
\hline $\begin{array}{l}\text { Statements in the annual report } \\
\text { concerning compliance with the } \\
\text { Combined Code on CG }\end{array}$ & 21.5 & 9.6 & 35.5 \\
\hline $\begin{array}{l}\text { Matters arising from compliance with } \\
\text { the Companies Acts and accounting } \\
\text { standards not covered above }\end{array}$ & 30.8 & 9.6 & 10.4 \\
\hline $\begin{array}{l}\text { Requirements of listing rules } \\
\text { prescribed by the Financial Services } \\
\text { Authority }\end{array}$ & 45.8 & 9.6 & 16.7 \\
\hline Total (\%) & 35.3 & 6.0 & 34.2 \\
\hline Total (No. of issues) & 1923 & 327 & 5445 \\
\hline
\end{tabular}


Note to table:

1. $\mathrm{AC}=$ full audit committee; $\mathrm{ACC}=$ audit committee chair; $\mathrm{CFO}=$ finance director; $\mathrm{AP}=$ audit partner. 
Table 7: Groupings involved in discussions for sub-samples - combined sample $(n=498)$

\begin{tabular}{|c|c|c|c|c|c|c|c|}
\hline & \multicolumn{7}{|c|}{ Grouping (\%) } \\
\hline Sub-group & $\begin{array}{c}\text { No AC or } \\
\text { ACC }\end{array}$ & $\begin{array}{c}\text { ACC no } \\
\text { AC }\end{array}$ & $\begin{array}{l}\text { No AP } \\
\text { or AC }\end{array}$ & No CFO & All in & No AC & No AP \\
\hline \multicolumn{8}{|l|}{ Panel (a) } \\
\hline \multicolumn{8}{|l|}{ Company size: } \\
\hline FTSE 350 & 32.2 & 4.7 & 5.3 & 2.1 & 57.6 & 36.8 & 10.6 \\
\hline Non-FTSE & 40.9 & 8.5 & 11.4 & 1.1 & 42.7 & 49.3 & 17.3 \\
\hline$\chi^{2}$ & $41.1^{* * *}$ & $31.0 * * *$ & $65.9 * * *$ & $7.3 * *$ & $110.8^{* * *}$ & $80.1^{* * *}$ & $49.8 * * *$ \\
\hline \multicolumn{8}{|l|}{ Panel (b) } \\
\hline \multicolumn{8}{|l|}{ Auditor tier: } \\
\hline Big Four & 35.2 & 5.8 & 7.7 & 2.3 & 52.8 & 41.0 & 13.2 \\
\hline Non-Big Four & 38.1 & 7.9 & 7.0 & 1.5 & 45.3 & 46.0 & 14.2 \\
\hline$\chi^{2}$ & 2.0 & $4.0 * *$ & 0.3 & 1.7 & $12.0 * * *$ & $5.5 * *$ & 0.5 \\
\hline
\end{tabular}

Notes to table:

1. $\mathrm{AC}=$ full audit committee; $\mathrm{ACC}=$ audit committee chair; $\mathrm{CFO}=$ finance director; $\mathrm{AP}=$ audit partner.

2. $\quad *=$ significant at $10 \%$ level; $* *=$ significant at $5 \%$ level; $* * *=$ significant at $1 \%$ level. 


\section{Appendix}

Panel (a): By company size

\begin{tabular}{|l|r|r|r|r|r|r|}
\hline \multicolumn{1}{c|}{$\begin{array}{c}\text { Parties } \\
\text { involved }\end{array}$} & \multicolumn{3}{c|}{ FTSE 350} & \multicolumn{3}{c|}{ Non-FTSE 350} \\
\hline & \multicolumn{1}{c|}{ No. } & \multicolumn{1}{c|}{ Rank } & No. & \multicolumn{1}{c|}{ \% } & Rank \\
\hline CFO only & 155 & 4.4 & 4 & 198 & 10.1 & 4 \\
\hline AP only & 30 & 0.8 & & 2 & 0.1 & \\
\hline ACC only & 1 & 0.0 & & 4 & 0.2 & \\
\hline AC only & 30 & 0.8 & & 6 & 0.3 & \\
\hline CFO + AP & 939 & 26.7 & 2 & 609 & 31.0 & 1 \\
\hline CFO + ACC & 28 & 0.8 & & 23 & 1.2 & 8 \\
\hline CFO + AC & 90 & 2.6 & 6 & 60 & 3.0 & 6 \\
\hline AP + ACC & 2 & 0.1 & & 1 & 0.1 & \\
\hline AP + AC & 7 & 0.2 & & 4 & 0.2 & \\
\hline ACC + AC & 2 & 0.1 & & 2 & 0.1 & \\
\hline CFO+AP+ACC & 130 & 3.7 & 5 & 139 & 7.1 & 5 \\
\hline CFO+AP + AC & 556 & 15.8 & 3 & 292 & 14.8 & 3 \\
\hline CFO+ACC+AC & 65 & 1.8 & 7 & 52 & 2.6 & 7 \\
\hline AP + ACC +AC & 3 & 0.1 & & 5 & 0.3 & \\
\hline All 4 & 1482 & 42.1 & 1 & 569 & 28.9 & 2 \\
\hline Total & $\mathbf{3 5 2 0}$ & $\mathbf{1 0 0 . 0}$ & & $\mathbf{1 9 6 6}$ & $\mathbf{1 0 0 . 0}$ & \\
\hline
\end{tabular}

Panel (b): By audit firm tier

\begin{tabular}{|l|r|r|r|r|r|r|}
\hline \multicolumn{1}{|c|}{$\begin{array}{c}\text { Parties } \\
\text { involved }\end{array}$} & \multicolumn{3}{c|}{ Big Four } & \multicolumn{3}{c|}{ Non Big Four } \\
\hline & \multicolumn{1}{|c|}{ No. } & \multicolumn{1}{c|}{ Rank } & \multicolumn{1}{c|}{ No. } & \multicolumn{1}{c|}{$\%$} & Rank \\
\hline CFO only & 327 & 6.6 & 4 & 29 & 4.6 & 6 \\
\hline AP only & 32 & 0.7 & & 0 & 0.0 & \\
\hline ACC only & 5 & 0.1 & & 0 & 0.0 & \\
\hline AC only & 37 & 0.8 & & 1 & 0.2 & \\
\hline CFO + AP & 1356 & 27.5 & 2 & 206 & 32.6 & 1 \\
\hline CFO + ACC & 40 & 0.8 & & 13 & 2.1 & 7 \\
\hline CFO + AC & 126 & 2.6 & 6 & 34 & 5.4 & $4=$ \\
\hline AP + ACC & 4 & 0.1 & & 0 & 0.0 & \\
\hline AP + AC & 32 & 0.7 & & 3 & 0.5 & \\
\hline ACC + AC & 4 & 0.1 & & 0 & 0.0 & \\
\hline CFO+AP+ACC & 235 & 4.8 & 5 & 34 & 5.4 & $4=$ \\
\hline CFO+AP + AC & 749 & 15.2 & 3 & 106 & 16.8 & 3 \\
\hline CFO+ACC+AC & 107 & 2.2 & 7 & 10 & 1.6 & 8 \\
\hline AP + ACC +AC & 2 & 0.0 & & 6 & 0.9 & \\
\hline All 4 & 1861 & 37.8 & 1 & 189 & 29.9 & 2 \\
\hline Total & $\mathbf{4 9 1 7}$ & $\mathbf{1 0 0 . 0}$ & & $\mathbf{6 3 1}$ & $\mathbf{1 0 0 . 0}$ & \\
\hline
\end{tabular}

Note to table:

1. $\mathrm{AC}=$ full audit committee; $\mathrm{ACC}=$ audit committee chair; $\mathrm{CFO}=$ finance director; $\mathrm{AP}=$ audit partner. 